\title{
ANALISIS KADAR NITROGEN (N) DALAM PUPUK NPK REAKSI PT. PETROKIMIA GRESIK MENGGUNAKAN METODE IN HOUSE DAN SNI- INOVASI
}

SKRIPSI

Diajukan untuk Memenuhi Sebagian Syarat Guna Memperoleh Gelar Sarjana Sains dalam Ilmu Kimia

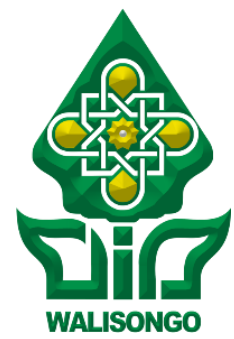

Oleh:

Nida Awalia

NIM: 1708036013

\section{FAKULTAS SAINS DAN TEKNOLOGI}

UNIVERSITAS ISLAM NEGERI WALISONGO

SEMARANG

2021 


\section{PERNYATAAN KEASLIAN}

Yang bertandatangan dibawah ini:

Nama : Nida Awalia

NIM : :1708036013

Jurusan : Kimia

Menyatakan bahwa skripsi yang berjudul:

Analisa Kadar Nitrogen (N) dalam Pupuk NPK Reaksi PT.

Petrokimia Gresik Menggunakan Metode in house dan

SNI-Inovasi

Secara keseluruhan adalah hasil penelitian/karya saya sendiri, kecuali bagian tertentu yang dirujuk sumbernya.

Semarang, 25 Maret 2021

Pembuat Pernyataan,

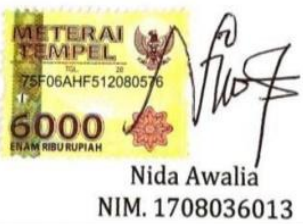




\section{PENGESAHAN}

Naskah skripsi berikut ini:

Judul : Analisis Kadar Nitrogen (N) dalam Pupuk NPK Reaksi PT. Petrokimia Gresik Menggunakan Metode in house dan SNI-Inovasi

Nama : Nida Awalia

NIM : 1708036013

Jurusan : Kimia

Telah diujikan dalam sidang munaqosah oleh Dewan Penguji Fakultas Sains dan Teknologi UIN Walisongo dan dapat diterima sebagai salah satu syarat memperoleh gelar Sarjana Sains dalam bidang Ilmu Kimia.

Semarang, 29 Maret 2021

DEWAN PENGUJI

Ketua Sidang,

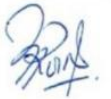

Sekretaris Sidang,

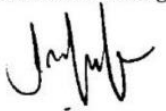

Dr. Ervin Tri Suryandari, M.Si

Hj. Malikhatul Hidayah, S.T, M.Pd NIP. 197407162009122 STIXERIAN AG NIP. 198304152009122006

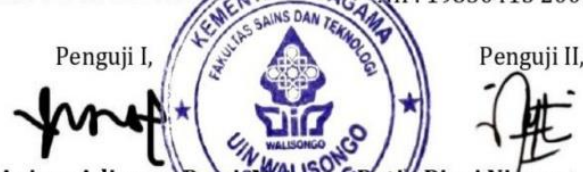

Dr.Eng. Anissa Adiwena Rut xis s.4 NIP. 19850405201101 PPG OLIK INDONE IP. 198104142005012003

Pembimbing I,

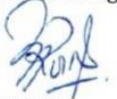

Dr. Ervin Tri Suryandari, M.Si NIP. 197407162009122001
Pembimbing II,

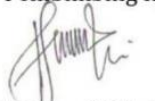

Mulyatun, S.Pd., M.Si. NIP.19830504 2011012008 


\section{NOTA DINAS}

Semarang, 24 Maret 2021

Yth. Ketua Program Studi Kimia

Fakultas Sains dan Teknologi

UIN Walisongo Semarang

Assalamualaikum. Wr. $\mathrm{Wb}$.

Dengan ini diberitahukan bahwa saya telah melakukan bimbingan, arahan dan koreksi naskah skripsi dengan:

Judul : Analisis Kadar Nitrogen (N) dalam Pupuk NPK

Reaksi PT. Petrokimia Gresik Menggunakan

Metode in house dan SNI-Inovasi

Nama : Nida Awalia

NIM : :1708036013

Jurusan : Kimia

Saya memandang bahwa naskah skripsi tersebut sudah dapat diajukan kepada Fakultas Sains dan Teknologi UIN Walisongo Semarang untuk diujikan dalam Sidang Munaqosah.

Wassalamu'alaikum. Wr. Wb.

Dosen Pembimbing I

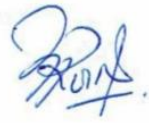

Dr. Ervin Tri Suryandari, M.Si

NIP. 197407162009122001 


\section{NOTA DINAS}

Semarang, 24 Maret 2021

Yth. Ketua Program Studi Kimia

Fakultas Sains dan Teknologi

UIN Walisongo Semarang

Assalamualaikum. Wr. Wb.

Dengan ini diberitahukan bahwa saya telah melakukan bimbingan, arahan dan koreksi naskah skripsi dengan:

Judul : Analisis Kadar Nitrogen (N) dalam Pupuk NPK

Reaksi PT. Petrokimia Gresik Menggunakan

Metode in house dan SNI-Inovasi

Nama : Nida Awalia

NIM : :1708036013

Jurusan : Kimia

Saya memandang bahwa naskah skripsi tersebut sudah dapat diajukan kepada Fakultas Sains dan Teknologi UIN Walisongo Semarang untuk diujikan dalam Sidang Munaqosah.

Wassalamu'alaikum. Wr. Wb.

Dosen Pembimbing II

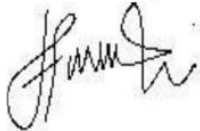

Mulyatun, S.Pd., M.Si

NIP. 198305042011012008 


\begin{abstract}
ABSTRAK
Analisis kandungan nitrogen dalam pengujian ini dilakukan dengan menggunakan metode in house dan SNIInovasi. Kedua metode ini dilakukan untuk mengetahui signifikansi dari penggunaan metode in house dan SNI-Inovasi dalam menentukan kandungan $\mathrm{N}$ pada pupuk NPK Reaksi. Keduanya memanfaatkan prinsip dasar teknik Kjeldahl yang melalui tiga fase, khususnya destruksi, destilasi, dan titrasi. Uji statistik yang diperhitungkan adalah uji kecukupan data, uji akurasi data dan presisi, serta uji T. Rerata kadar nitrogen pupuk NPK Reaksi metode in house dan SNI-Inovasi berturutturut sebesar $14.8551 \% \mathrm{~b} / \mathrm{b}$ dan $15.386 \% \mathrm{~b} / \mathrm{b}$. Hasil uji statistik membuktikan bahwa metode in house dan SNIInovasi tidak berbeda nyata secara signifikan. Oleh karena itu, metode SNI-Inovasi bisa direkomendasikan menjadi metode analisa pada penetapan kadar nitrogen dalam pupuk NPK Reaksi di PT. Petrokimia Gresik.
\end{abstract}

Kata kunci: pupuk NPK Reaksi, metode in house, kadar N. metode SNI-Inovasi 


\section{KATA PENGANTAR}

Assalamu'alaikum Warahmatullahi Wabarakatuh

Puji syukur penulis panjatkan atas kebajikan Allah SWT yang telah melimpahkan karunia dan ridho-Nya, sehingga penulis dapat menyelesaikan skripsi ini dengan sebaik-baiknya. Shalawat serta salam tidak lupa penulis panjatkan kepada panutan umat Islam yaitu baginda Rasul Nabi Muhammad SAW yang telah membawa manusia dari kehidupan yang gelap menuju kehidupan yang terang benderang dengan penuh Rahmatan Lil'alamin.

Skripsi ini disusun sebagai persyaratan guna memperoleh gelar sarjana sains ilmu kimia di UIN Walisongo Semarang, Fakultas Sains dan Teknologi, Program Studi Kimia. Pada kesempatan ini penulis mengucapkan banyak terima kasih kepada:

1. Prof. Dr. H. Imam Taufiq, M.Ag. selaku Rektor UIN Walisongo Semarang.

2. Dr. H. Ismail, M.Ag. selaku Dekan Fakultas Sains dan Teknologi UIN Walisongo Semarang.

3. Hj. Malikhatul Hidayah, S.T., M.Pd. sebagai Ketua Program Studi Kimia

4. Dr. Ervin Tri Suryandari, M.Si. selaku Dosen Pembimbing I. 
5. Mulyatun, S.Pd., M.Si selaku Dosen Pembimbing II.

6. Bapak/Ibu dosen dan staff Program Studi Kimia Fakultas Sains dan Teknologi UIN Walisongo Semarang.

7. Keluarga penulis yaitu H. Muzani dan $\mathrm{Hj}$. Soidatun yang selalu mendorong dan mendo'akan agar skripsi ini cepat selesai, serta adik M. Dani Amrullah dan Masdar Nata Wijaya yang selalu mendo'akan dan memberikan semangat kepada penulis.

8. Teman-teman Program Studi Kimia angkatan 2017 Fakultas Sains dan Teknologi UIN Walisongo Semarang yang telah membantu dan memotivasi penulis.

9. Dan seluruh pihak yang tidak dapat penulis sebutkan satu persatu.

Akhir kata penulis mengharapkan semoga skripsi ini dapat bermanfaat bagi penulis dan Mahasiswa Program Studi Kimia UIN Walisongo Semarang khususnya serta rekan-rekan pembaca pada umumnya bagi kemajuan ilmu pengetahuan dan teknologi.

Wassalamu'alaikum Warahmatullahi Wabarakatuh

Semarang, 25 Maret 2021

Penulis 


\section{DAFTAR ISI}

PERNYATAAN KEASLIAN ................................................................ii

PENGESAHAN ...................................................................................ii

NOTA DINAS.....................................................................................iv

ABSTRAK …...................................................................................... vi

KATA PENGANTAR............................................................................vii

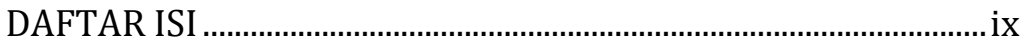

DAFTAR TABEL.................................................................................

DAFTAR GAMBAR...............................................................................

DAFTAR LAMPIRAN........................................................................ xiii

BAB I PENDAHULUAN ................................................................ 1

A. Latar Belakang.................................................................. 1

B. Rumusan Masalah ................................................................ 4

C. Tujuan Penelitian....................................................................... 4

D. Manfaat Penelitian .............................................................. 4

BAB II LANDASAN TEORI ................................................................ 5

A. Pupuk NPK .......................................................................... 5

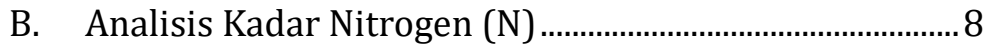

1. Tahap Destruksi ................................................................ 8

2. Tahap Destilasi ................................................................. 9

3. Tahap Titrasi.................................................................. 10

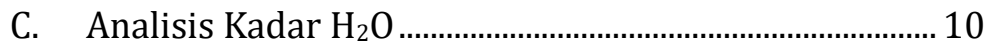

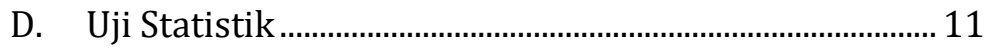

1. Uji Kecukupan Data........................................................ 11 
2. Uji Presisi .......................................................................... 12

3. Uji Akurasi ........................................................................ 13

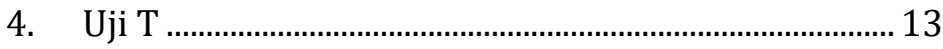

E. Kajian Pustaka ………………………………………….... 14

BAB III METODE PENELITIAN …………………………………... 17

A. Alat dan Bahan ......................................................................... 17

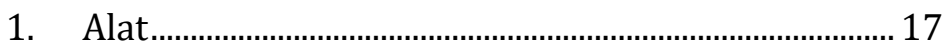

2. Bahan ............................................................................ 17

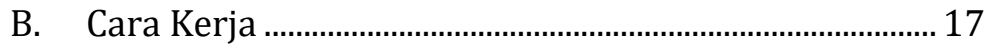

1. Pengujian Kadar $\mathrm{H}_{2} \mathrm{O}$.................................................... 17

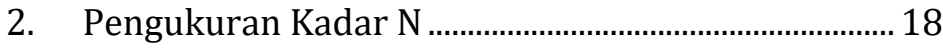

C. Pengujian Statistik ........................................................... 20

1. Uji Kecukupan Data.......................................................... 20

2. Uji Presisi ........................................................................... 21

3. Uji Akurasi .................................................................... 22

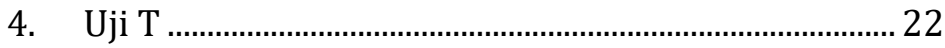

BAB IV HASIL DAN PEMBAHASAN .................................................. 24

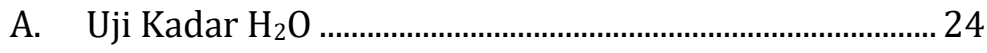

B. Kadar N Pupuk NPK Reaksi...………………………….... 25

C. Uji Statistik ……………………………………………..... 26

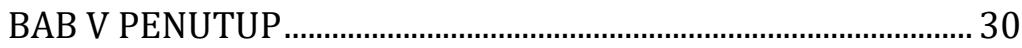

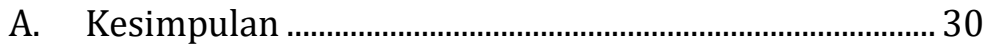

B. Saran .................................................................................... 30

DAFTAR PUSTAKA.............................................................................. 31

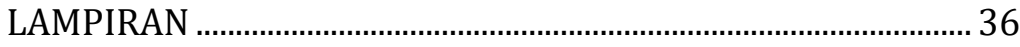




\section{DAFTAR TABEL}

Tabel 2.1 Spesifikasi Persyaratan Mutu Kandungan Unsur Pada Pupuk NPK Padat ................................................. 7

Tabel 4.1 Hasil Uji Kadar $\mathrm{H}_{2} \mathrm{O}$.......................................................... 24

Tabel 4.2 Hasil Uji Kadar N pada Pupuk NPK Reaksi............... 25 


\section{DAFTAR GAMBAR}

Gambar 4.1 Grafik Kontrol Hasil Uji Akurasi pada Metode in house .............................................................................. 27

Gambar 4.2 Grafik Kontrol Hasil Uji Akurasi pada Metode SNI-

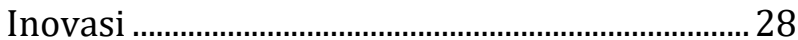




\section{DAFTAR LAMPIRAN}

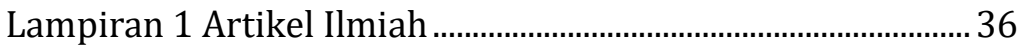

Lampiran 2 Perhitungan Analisa ................................................... 41 


\section{BAB I \\ PENDAHULUAN}

\section{A. Latar Belakang}

PT. Petrokimia Gresik adalah anak perusahaan milik negara PT. Pupuk Indonesia (Persero) yang memiliki dua macam produk yaitu pupuk dan non pupuk serta bahan kimia untuk keperluan industri. Produk pupuk yang dibuat oleh PT. Petrokimia Gresik, meliputi pupuk SP-36, pupuk urea, pupuk phonska, pupuk ZA, pupuk phonska oca, pupuk spesifikasi komoditi, pupuk petroganik, pupuk phonska plus, pupuk rock phospate, pupuk ZK, pupuk petro niphos, pupuk KCl, pupuk petro ningrat, pupuk petro bio fertil, dan pupuk petro nitrat. Salah satu produk pupuk yang diproduksi adalah pupuk NPK Reaksi (PT Petrokimia Gresik, 2019). Pupuk NPK Reaksi dibuat dengan memanfaatkan siklus reaksi antara ammoniak dan fosfat untuk menghasilkan DAP (diammonium fosfat) sebagai bahan dasar komponen N dan P. Sedangkan pupuk NPK granulasi dibuat tanpa melalui siklus reaksi antara ammoniak dan fosfat, dimana bahan bakunya dalam bentuk padat sehingga tinggal di mix. Komponen yang terkandung dalam pupuk NPK Reaksi adalah nitrogen, fosfor, dan kalium. Nitrogen (N) 
merupakan suplemen yang memiliki peran penting dalam pengaturan dan pemicu perkembangan tanaman secara keseluruhan, namun jika jumlahnya berlebihan dapat menghambat pembungaan dan pembuahan tanaman (Wiyantoko, dkk. 2017). Tingginya kadar nitrogen sangat mempengaruhi berat dan panjang perkembangan tanaman (Tjahjaningsih dkk, 2019). Strategi analisa kandungan nitrogen yang digunakan dalam penelitian ini adalah teknik Kjeldahl. Pada dasarnya nitrogen dengan teknik Kjeldahl melalui tiga fase yaitu destruksi, destilasi dan titrasi (Milis Y dan Anjar PA, 2019). Pengujian kadar N dalam pupuk NPK Reaksi diselesaikan dengan menggunakan metode in house dan strategi SNI-Inovasi, kedua metode menggunakan teknik kjeldahl yang terdiri dari tahapan destruksi, destilasi, dan titrasi (Milis Y dan Anjar PA, 2019).

Metode in house adalah standar yang digunakan rutin di PT. Petrokimia Gresik dengan mengacu pada SNI dan ASTM (American Society for Testing and Material) sedangkan metode SNI-Inovasi merupakan pengembangan dari metode in house sebagai pilihan lain pada penetapan kadar $\mathrm{N}$ dalam pupuk NPK Reaksi dengan tujuan untuk mengetahui signifikansi penggunaan metode in house dan SNI- 
Inovasi pada penetapan kadar $\mathrm{N}$ dalam pupuk NPK Reaksi di PT. Petrokimia Gresik. Pengembangan pada metode SNI-Inovasi terletak pada reagen yang digunakan dan destrat kemudian didinginkan, dimasukkan ke dalam labu ukur $500 \mathrm{~mL}$ dan ditambahkan akuades hingga tanda tera. Uji statistik yang diperhitungkan adalah uji kecukupan data, uji akurasi data dan presisi, serta uji T. Hasil uji statistik digunakan untuk membuktikan apakah suatu hipotesis yang dibuat dapat diterima atau tidak.

Metode SNI-Inovasi digunakan untuk mencoba mencari pilihan yang berbeda dalam rangka meningkatkan keefektifan dan keefisienan dalam proses analisis kadar $\mathrm{N}$, sehingga digunakan dua metode untuk mengetahui signifikansi penggunaan metode in house dan SNI-Inovasi pada penetapan kadar N dalam pupuk NPK Reaksi dan dapatkan metode SNI-Inovasi menjadi rekomendasi pada analisa penetapan kadar N dalam pupuk NPK Reaksi di PT. Petrokimia Gresik. Peningkatan keefektifan dan keefisienan tersebut terjadi dengan alasan bahwa penggunaan metode SNI-Inovasi akan menghasilkan produk sesuai dengan SNI (Standar Nasional Indonesia) 2803 tahun 2012 tentang Pupuk NPK. Hal ini dapat meningkatkan kepercayaan konsumen 
bahwa pupuk NPK yang diproduksi oleh PT. Petrokimia Gresik memiliki kualitas yang baik.

\section{B. Rumusan Masalah}

Berdasarkan latar belakang di atas, maka dapat diambil perumusan masalah sebagai berikut "Bagaimana signifikansi penggunaan metode in house dan SNI-Inovasi pada penetapan kadar N dalam pupuk NPK Reaksi?".

\section{Tujuan Penelitian}

Tujuan dalam penelitian ini adalah untuk mengetahui signifikansi penggunaan metode in house dan SNI-Inovasi pada penetapan kadar N dalam pupuk NPK Reaksi.

\section{Manfaat Penelitian}

Manfaat dalam penelitian ini adalah dapat menghasilkan produk yang sesuai dengan Standar Nasional Indonesia (SNI) 2803 tahun 2012 tentang pupuk NPK Padat dan meningkatkan kepercayaan bagi konsumen bahwa pupuk NPK yang dihasilkan PT. Petrokimia Gresik itu berkualitas. 


\section{BAB II}

\section{LANDASAN TEORI}

\section{A. Pupuk NPK}

Pupuk NPK adalah salah satu produk pupuk PT. Petrokimia Gresik berbentuk granul dengan kandungan unsur hara nitrogen, fosfor, dan kalium. Pupuk NPK merupakan salah satu jenis pupuk anorganik yang sering digunakan oleh masyarakat dalam bidang pertanian dan perkebunan. Kandungan unsur hara dalam pupuk NPK yaitu nitrogen dalam bentuk $\mathrm{NH}_{3}$, fosfor dalam bentuk $\mathrm{P}_{2} \mathrm{O}_{5}$, dan kalium dalam bentuk $\mathrm{K}_{2} \mathrm{O}$ (Wiyantoko, dkk. 2017). Maksud dari pupuk NPK Reaksi adalah pupuk NPK yang dibuat dengan menggunakan proses reaksi antara ammoniak dengan asam fosfat untuk menghasilkan DAP (diammonium phospate) sebagai bahan dasar dari unsur $\mathrm{N}$ dan $\mathrm{P}$, dimana pupuk tersebut dapat berupa pupuk NPK Phonska, pupuk NPK Phonska Plus dan pupuk NPK Kebomas. Pada PT. Petrokimia Gresik itu sendiri ada 8 pabrik yang bekerja dalam pembuatan pupuk NPK, 4 pabrik dengan proses pembuatan secara granulasi atau bisa disebut dengan NPK Granulasi dan 4 pabrik yang lain dengan proses 
pembuatan secara reaksi atau bisa disebut dengan NPK Reaksi.

Pupuk anorganik yang dapat digunakan dalam rangka pemenuhan kebutuhan unsur hara tanaman adalah pupuk NPK. Kelebihan penggunaan pupuk NPK adalah mencakup beberapa unsur dalam satu kali pemberian pupuk sehingga dirasa lebih efisien (Dede Haryadi, dkk. 2015). Penggunaan pupuk NPK dapat dijadikan sebagai alternatif untuk meningkatkan pertumbuhan tanaman dan kandungan unsur hara yang dibutuhkan tanaman di dalam tanah. Pupuk NPK ini menjadi satu-kesatuan yang sangat dibutuhkan tanaman, tanpa adanya suplai nitrogen yang cukup maka pertumbuhan yang baik pada tanaman tidak akan terjadi. Hal ini dikarenakan apabila suatu tanaman kekurangan unsur hara $\mathrm{N}$ maka akan menunjukkan pertumbuhan yang kerdil, pertumbuhan akar terbatas, dan daun menjadi warna kuning pucat (Hasibuan, 2006). Peranan utama unsur hara $\mathrm{N}$ itu sendiri adalah merangsang pertumbuhan secara keseluruhan, baik batang, cabang, maupun daun (Lingga, 2001).

Tanaman dengan kekurangan unsur hara $\mathrm{P}$ juga akan berakibat pada pertumbuhan tanaman yang kerdil, dikarenakan pembelahan sel terganggu. 
Kegunaan P sebagai pembentukan daun sedangkan $\mathrm{K}$ sebagai pembentukan akar, mengatur air pada tanaman dan membantu proses translokasi fotosintesis. Jika tanaman kekurangan K maka batang dan cabang lemah dan rebah, biji buah mengkusut, serta daunnya akan bercak-bercak coklat (Afif, 2015). Menurut Badan Standardisasi Nasional (2012) 2803 tahun 2012 mengenai spesifikasi persyaratan mutu kandungan unsur pada pupuk NPK padat dapat ditunjukkan pada tabel 2.1:

Tabel 2.1 Spesifikasi Persyaratan Mutu Kandungan Unsur Pada Pupuk NPK Padat

\begin{tabular}{|c|c|c|c|}
\hline Jenis Uji & Satuan & Persyaratan & $\begin{array}{c}\text { Batas Tolerasi } \\
\text { Minimal yang } \\
\text { Dipersyaratkan }\end{array}$ \\
\hline $\begin{array}{l}\text { Nitrogen } \\
\text { total* }\end{array}$ & $\% \mathrm{~b} / \mathrm{b}$ & \multirow{4}{*}{$\begin{array}{c}\text { Sesuai } \\
\text { formula } \\
\text { yang ada } \\
\text { di tabel }\end{array}$} & $8 \%$ \\
\hline $\begin{array}{l}\text { Fosfor } \\
\text { sebagai } \\
\mathrm{P}_{2} \mathrm{O}_{5} \text { total }\end{array}$ & $\% \mathrm{~b} / \mathrm{b}$ & & $8 \%$ \\
\hline $\begin{array}{l}\text { Kalium } \\
\text { sebagai } \\
\mathrm{K}_{2} \mathrm{O}\end{array}$ & $\% \mathrm{~b} / \mathrm{b}$ & & $8 \%$ \\
\hline $\begin{array}{l}\text { Jumlah } \\
\text { kadar N, } \\
\mathrm{P}_{2} \mathrm{O}_{5}, \mathrm{~K}_{2} \mathrm{O}\end{array}$ & $\% \mathrm{~b} / \mathrm{b}$ & & $8 \%$ \\
\hline Kadar air & $\% \mathrm{~b} / \mathrm{b}$ & Maks.3 & - \\
\hline $\begin{array}{l}\text { Cemaran } \\
\text { logam: }\end{array}$ & & & \\
\hline $\begin{array}{l}\text { - Raksa } \\
\text { (Hg) }\end{array}$ & $\mathrm{mg} / \mathrm{kg}$ & Maks.10 & - \\
\hline
\end{tabular}




\begin{tabular}{|c|c|c|c|}
\hline Jenis Uji & Satuan & Persyaratan & $\begin{array}{c}\text { Batas Tolerasi } \\
\text { Minimal yang } \\
\text { Dipersyaratkan }\end{array}$ \\
\hline $\begin{array}{c}\text {-Kadmium } \\
(\mathrm{Cd})\end{array}$ & $\mathrm{mg} / \mathrm{kg}$ & Maks.100 & - \\
\hline -Timbal (Pb) & $\mathrm{mg} / \mathrm{kg}$ & Maks.500 & - \\
\hline Arsen (As) & $\mathrm{mg} / \mathrm{kg}$ & Maks.100 & - \\
\hline
\end{tabular}

Ket: *adalah ADBK (Atas Dasar Berat Kering)

Persyaratan yang telah ditetapkan oleh PT.

Petrokimia Gresik untuk kadar pupuk NPK adalah $15 \%$ masing-masing unsur dengan syarat keberterimaan $(13,5-16,5) \% b / b$ untuk ADBK.

\section{B. Analisis Kadar Nitrogen (N)}

Analisa kadar nitrogen pada metode in house dan metode SNI-Inovasi keduanya menggunakan prinsip metode kjeldahl. Pada dasarnya analisa nitrogen dengan metode kjeldahl melalui tiga tahapan, yaitu:

1. Tahap Destruksi

Destruksi adalah suatu proses penghancuran senyawa menjadi unsur-unsurnya, dimana elemen karbon, hidrogen teroksidasi menjadi $\mathrm{CO}, \mathrm{CO}_{2}$, dan $\mathrm{H}_{2} \mathrm{O}$ sedangkan nitrogennya berubah menjadi $\left(\mathrm{NH}_{4}\right)_{2} \mathrm{SO}_{4}$. Pada dasarnya terdapat dua macam destruksi, yaitu destruksi basah dan destruksi kering. Keduanya mempunyai teknik pengerjaan dan lama pemanasan yang berbeda-beda (Kristianingrum, 2012). 
Analisis nitrogen dalam penelitian ini menggunakan metode destruksi basah. Pelarut yang dapat digunakan pada destruksi basah adalah $\mathrm{HNO}_{3}, \mathrm{H}_{2} \mathrm{SO}_{4}, \mathrm{HClO}_{4}$, dan $\mathrm{HCl}$. Proses destruksi dikatakan selesai apabila telah diperoleh larutan jernih pada larutan destruksi. Hal ini menunjukkan konstituen yang ada telah larut secara sempurna dan penghancuran senyawasenyawa berjalan dengan baik (Kristianingrum, 2012).

2. Tahap Destilasi

Destilasi adalah salah satu teknik pemisahan kimia untuk memisahkan dua atau lebih komponen dalam suatu senyawa berdasarkan perbedaan titik didih (Walangare dkk, 2013). Prinsip dasar destilasi adalah perbedaan titik didih dalam suatu campuran dan larutan dengan titik didih yang lebih rendah akan menguap terlebih dahulu dibandingkan yang lain (Suradi dkk, 2015).

Proses destruksi menjadikan pemecahan $\left(\mathrm{NH}_{4}\right)_{2} \mathrm{SO}_{4}$ menjadi $\mathrm{NH}_{3}$ dengan penambahan reagen. Ammonia yang terbebas akan ditangkap oleh larutan standar asam atau disebut dengan penjerap. Penjerap yang digunakan dalam 
penelitian ini adalah $\mathrm{H}_{2} \mathrm{SO}_{4}, 0,5 \mathrm{~N}$ pada metode in house dan $\mathrm{H}_{3} \mathrm{BO}_{3} 1 \%$ pada metode SNI-Inovasi.

3. Tahap Titrasi

Titrasi adalah metode analisis kimia yang dilakukan untuk menentukan konsentrasi suatu reaktan. Ada tiga reaksi kimia yang digunakan sebagai dasar titrasi yaitu: 1) reaksi asam kuat dan basa kuat, 2) reaksi asam lemah dan basa kuat, dan 3) reaksi asam kuat dan basa lemah (Chang, 2005). Dalam tahap titrasi ada beberapa hal yang harus diperhatikan yaitu: 1) larutan standar, 2) indikator, dan 3) perhitungan konsentrasi larutan yang ditentukan.

Titrasi yang dilakukan dalam penelitian ini adalah titrasi asam-basa. Titrasi asam-basa adalah titrasi yang melibatkan asam dan basa sebagai titer ataupun titran (Simanjuntak, 2018). Prinsip titrasi asam-basa adalah penetapan kadar asam dengan menggunakan larutan standar basa dan penetapan kadar basa dengan menggunakan larutan standar asam (Ulfa, Retnaningsih dan Aufa, 2017).

\section{Analisis Kadar $\mathrm{H}_{2} \mathrm{O}$}

Analisis kadar air menjadi salah satu uji laboratorium kimia yang sangat penting, dimana hal 
ini dilakukan untuk menentukan ketahanan terhadap kerusakan yang mungkin bisa terjadi (Daud dkk, 2019). Kadar $\mathrm{H}_{2} \mathrm{O}$ pada pupuk diukur dengan metode Karl Fischer Titration menggunakan alat karl fischer dengan menekan tombol start dan akan berakhir otomatis jika telah mencapai titik akhir. Metode KFT (Karl Fischer Titration) menggunakan larutan hidranal karena mempunyai kemampuan dalam mengukur kadar $\mathrm{H}_{2} \mathrm{O}$ pada sampel yang berbentuk cairan dan padatan (Farida dkk, 2000).

\section{Uji Statistik}

1. Uji Kecukupan Data

Uji kecukupan data dilakukan untuk memastikan apakah data yang diambil peneliti sudah cukup untuk mewakili suatu populasi. Oleh karena itu, pengambilan data diperlukan jumlah yang banyak untuk mengantisipasi apabila data yang diambil belum cukup. Jumlah data yang diambil dilakukan berdasarkan tingkat keyakinan peneliti. Data pengamatan dianggap cukup apabila $\mathrm{N}^{\prime}<\mathrm{N}($ Sokhibi, 2017).

$$
N^{\prime}=\left(\frac{k}{S} \frac{\sqrt{N \Sigma x^{2}-\left(\sum x^{2}\right)}}{\Sigma x}\right)^{2}
$$

Keterangan:

$\mathrm{N}^{\prime}=$ Jumlah data seharusnya 
$\mathrm{N}=$ Jumlah data yang didapat

$\mathrm{k}=$ Tingkat kepercayaan dalam pengamatan $(\mathrm{k}=2$,

$1-\alpha=95 \%)$

$S=$ Derajat ketelitian dan pengamatan

$\mathrm{X}=$ Kadar $\mathrm{N}$

(Purnomo, 2004).

2. Uji Presisi

Uji presisi dilakukan dengan tujuan untuk mengetahui kedekatan hasil-hasil pengujian yang telah diperoleh menggunakan sampel, metode, analis, peralatan, dan laboratorium yang sama (Sa dan Surya, 2010). Ketelitian yang baik adalah apabila nilai \%RSD < 2/3CV Horwitz (Harvey D, 2000).

$$
\% R S D=\frac{\sigma}{\bar{X}} \times 100 \%
$$

Keterangan:

$$
\begin{array}{ll}
\mathrm{RSD} & =\text { Standar deviasi relatif } \\
\sigma & =\text { Simpangan baku } \\
\overline{\mathrm{X}} & =\text { Rata-rata kadar } \mathrm{N}
\end{array}
$$

$$
\text { CV Horwitz }=2^{1-0,5 \log c}
$$

dengan:

$$
c=\frac{\sigma}{100}=\text { fraksi } \mathrm{kadar}
$$

(Utami, 2017). 
3. Uji Akurasi

Uji akurasi dilakukan dengan tujuan untuk menentukan populasi data sampel yang digunakan memiliki penyimpangan yang normal dari rataratanya pada tingkat kepercayaan tertentu.

$$
\begin{aligned}
& \text { Upper Control Line }(\mathrm{UCL})=\bar{X}+3 \sigma \\
& \text { Lower Control Line }(\mathrm{LCL})=\bar{X}-3 \sigma
\end{aligned}
$$

(Rosidi dkk, 2011)

dengan:

$$
\sigma=\sqrt{\frac{\sum(X-\bar{X})^{2}}{N-1}}
$$

Keterangan:

$$
\begin{aligned}
\sigma & =\text { Simpangan baku } \\
\mathrm{X} & =\text { Kadar } \mathrm{N} \\
\overline{\mathrm{X}} & =\text { Rata-rata kadar } \mathrm{N} \\
\mathrm{N} & =\text { Jumlah data pengamatan }
\end{aligned}
$$

Data dianggap seragam jika semua sampel data berada pada cakupan range antara batas atas (UWL) dan batas bawah (LWL) (Tuning dan Samin, 2012).

4. Uji T

Uji $\mathrm{T}$ dilakukan dengan tujuan untuk mengetahui apakah suatu hipotesis dapat diterima atau ditolak. Jika $\mathrm{T}_{\text {hitung }}<\mathrm{T}_{\text {tabel }}$ maka $\mathrm{H}_{0}$ diterima 
dan $\mathrm{H}_{1}$ ditolak, dan jika $\mathrm{T}_{\text {hitung }}>\mathrm{T}_{\text {tabel }}$ maka $\mathrm{H}_{0}$ ditolak dan $\mathrm{H}_{1}$ diterima (Santoso, 2018).

Hipotesis nol $\left(\mathrm{H}_{0}\right)$ : Rerata hasil pengujian metode in house dan metode SNI-inovasi tidak berbeda nyata secara signifikan.

Hipotesis alternatif $\left(\mathrm{H}_{1}\right)$ : Rerata hasil pengujian in house dan metode SNI-Inovasi berbeda nyata secara signifikan.

$$
T_{\text {hitung }}=\frac{\bar{X}_{1}-\bar{X}_{2}}{S_{\text {gabungan }\left(\sqrt{\frac{1}{N_{1}}}+\sqrt{\frac{1}{N_{2}}}\right)}}
$$

Keterangan:

$\overline{\mathrm{X}}_{1} \quad=$ Rata-rata kadar $\mathrm{N}$ metode in house

$\overline{\mathrm{X}}_{2}=$ Rata-rata kadar N metode SNI-Inovasi

$\mathrm{N}_{1}=$ Jumlah pengamatan metode in house

$\mathrm{N}_{2}$ = Jumlah pengamatan metode SNI-Inovasi

Sgab= Standar deviasi gabungan

\section{E. Kajian Pustaka}

Penelitian tentang analisis kadar nitrogen sudah pernah dilakukan, diantaranya yaitu penelitian yang dilakukan oleh Amalia dan Fajri, (2020)mengenai "Analisis Kadar Nitrogen dalam Pupuk Urea Prill dan Granule Menggunakan Metode Kjeldahl di PT Pupuk Iskandar Muda" yang didapatkan bahwa hasil analisis kadar nitrogen menggunakan 
metode kjeldahl tidak melewati batas parameternya yaitu minimal 46\% dan sesuai dengan kadar nitrogen yang dianjurkan oleh Kementrian Perindustrian. Mengacu pada jurnal tersebut maka dalam penelitian ini digunakanlah metode kjeldahl dalam analisis nitrogen dengan harapan menghasilkan kadar nitrogen yang dianjurkan oleh Kementrian Perindustrian.

Penelitian lain dilakukan oleh Milis Y dan Anjar PA, (2019) mengenai "Analisis Kadar Nitrogen pada Pupuk Urea, Pupuk Cair dan Pupuk Kompos dengan Metode Kjeldahl" yang dihasilkan bahwa persentase kadar nitrogen berturut-turut adalah 46,04; 2,79 dan 0,0360\%, dimana berdasarkan data tersebut pupuk urea dan pupuk kompos layak sebagai produk yang diperjual belikan karena memenuhi SNI 19-7030-2004 sedangkan pupuk cair tidak memenuhi SNI karena mempunyai nilai yang lebih rendah berdasarkan baku standar kadar nitrogen pupuk cair. Oleh karena itu, pada penelitian kali ini digunakanlah pupuk padat dengan harapan kadar nitrogen yang diperoleh sesuai dengan standar baku kadar nitrogen yang telah ditetapkan.

Penelitian selanjutnya dilakukan oleh Wiyantoko dkk, (2017) mengenai “Pengujian Nitrogen 
Total, Kandungan Air dan Cemaran Logam Timbal pada Pupuk Anorganik Nitrogen Phospor Kalium (NPK) Padat" yang didapatkan bahwa hasil uji pada sampel pupuk NPK Padat memenuhi syarat baku mutu SNI 2803:2010. Mengacu pada jurnal tersebut dihasilkan kadar nitrogen total pada pupuk NPK padat memenuhi syarat baku SNI 2803:2010 dengan menggunakan metode kjeldahl, maka dilakukan inovasi pada penelitian kali ini yaitu dengan metode SNI-Inovasi dimana dilakukan pengembangan pada reagen yang digunakan dan hasil destruksi sampel didinginkan serta dimasukkan ke dalam labu takar 500 mL. Kemudian dilakukan pengujian statistik untuk mengetahui signifikansi penggunaan metode in house dan SNI-Inovasi pada penetapan kadar N dalam pupuk NPK Reaksi. 


\section{BAB III \\ METODE PENELITIAN}

\section{A. Alat dan Bahan}

1. Alat

Alat yang digunakan dalam penelitian ini adalah labu ukur $500 \mathrm{~mL}$, spatula, pipet volume, neraca analitik. erlenmeyer, labu kjeldahl, alat destilasi vapodest, buret, dan alat destilasi.

2. Bahan

Bahan yang digunakan dalam penelitian ini adalah sampel produk pupuk NPK Reaksi, akuades, $\mathrm{H}_{2} \mathrm{SO}_{4} \quad 98 \%$ (Merck), $\mathrm{H}_{2} \mathrm{SO}_{4} \quad 0,5 \quad \mathrm{~N}$ (Merck), $\mathrm{H}_{2} \mathrm{SO}_{4}$ 0,05 $\mathrm{N}$ (Merck), $\mathrm{NaOH} 0,25 \mathrm{~N}$ (Merck), $\mathrm{H}_{3} \mathrm{BO}_{3} 1 \%$ (Merck), indikator conway, indikator PP, dan indikator mix acid.

\section{B. Cara Kerja}

1. Pengujian Kadar $\mathrm{H}_{2} \mathrm{O}$

Kadar $\mathrm{H}_{2} \mathrm{O}$ pada pupuk NPK Reaksi diukur dengan metode Karl Fischer Titration menggunakan alat karl fischer, dimulai dengan menekan tombol start dan akan berakhir otomatis jika telah mencapai titik akhir. Metode KFT (Karl Fischer Titration) menggunakan larutan hidranal karena mempunyai kemampuan dalam mengukur 
kadar $\mathrm{H}_{2} \mathrm{O}$ pada sampel yang berbentuk cairan dan padatan (Farida dkk, 2000).

2. Pengukuran Kadar $\mathrm{N}$

a. Metode in house

Tahap destruksi diawali dengan penimbangan sampel $\pm 0,8 \mathrm{~g}$ kemudian alat destruksi dipanaskan dan sampel dalam labu kjeldahl diberi sedikit akuades serta $\mathrm{H}_{2} \mathrm{SO}_{4}$ 98\% sebanyak $25 \mathrm{~mL}$. Proses dilanjutkan dengan penetesan indikator PP dalam labu kjeldahl yang telah selesai didestruksi.

Tahap destilasi diawali dengan pembuatan penjerap yaitu $\mathrm{H}_{2} \mathrm{SO}_{4}$ 0,5 N $25 \mathrm{~mL}$ dengan indikator mix acid dalam erlenmeyer. Sampel pada wadah labu kjeldahl dimasukkan ke alat destilasi vapodest lalu didestilasi sampai selesai.

Tahap titrasi dimulai dengan pembuatan titran yaitu $\mathrm{NaOH} \mathrm{0,25} \mathrm{N}$. Destilat dititrasi dengan $\mathrm{NaOH}$ 0,25 $\mathrm{N}$ untuk diketahui kadar nitrogen $(\% \mathrm{~N})$ pada sampel pupuk NPK Reaksi.

Persentase nitrogen dihitung dengan menggunakan rumus: 
$\% N=\frac{\left(N_{1} \times V_{1}\right)-\left(N_{2} \times V_{2}\right) \times 14 \times 100}{\text { bobot penimbangan }} F$

Keterangan:

$\mathrm{N} 1=$ Normalitas $\mathrm{H}_{2} \mathrm{SO}_{4}$

V1 = Volume $\mathrm{H}_{2} \mathrm{SO}_{4}$

$\mathrm{N} 2=$ Normalitas $\mathrm{NaOH}$

V2= Volume $\mathrm{NaOH}$

b. Metode SNI-Inovasi

Tahap destruksi diawali dengan penimbangan sampel $\pm 0,5 \mathrm{~g}$ kemudian alat destruksi dipanaskan dan sampel dalam labu kjeldahl diberi sedikit akuades serta $\mathrm{H}_{2} \mathrm{SO}_{4}$ 98\% sebanyak 25 mL. Dilanjutkan dengan pendinginan dan penambahan akuades hingga tanda tera dalam labu ukur 500 mL, kemudian dihomogenkan menggunakan magnetic stirrer dan diambil $25 \mathrm{~mL}$ menggunakan pipet volume dan dimasukkan kembali ke dalam labu kjeldahl. Proses dilanjutkan dengan penetesan indikator PP dalam labu kjeldahl.

Tahap destilasi diawali dengan pembuatan penjerap yaitu $\mathrm{H}_{3} \mathrm{BO}_{3} 1 \% 25 \mathrm{~mL}$ dengan indikator conway dalam erlenmeyer. Sampel pada wadah labu kjeldahl dimasukkan ke alat destilasi vapodest lalu didestilasi 
sampai selesai.

Tahap titrasi diawali dengan pembuatan titran yaitu $\mathrm{H}_{2} \mathrm{SO} 40,05 \mathrm{~N}$. Destilat dititrasi dengan $\mathrm{H}_{2} \mathrm{SO}_{4}$ 0,05 $\mathrm{N}$ untuk diketahui kadar nitrogen $(\% \mathrm{~N})$ pada sampel pupuk NPK Reaksi.

Persentase nitrogen dihitung dengan menggunakan rumus:

$\% \mathrm{~N}=\frac{V_{P} X N_{P} X A r N X F p}{\text { bobot sampel }(\mathrm{mg})} 100 \%$

Keterangan:

$\mathrm{Vp} \quad=$ Volume titran

$\mathrm{Np}=$ Normalitas titran

Ar $\mathrm{N}=$ Massa atom relatif $\mathrm{N}$ (14)

$\mathrm{Fp}=$ Faktor pengenceran

\section{Pengujian Statistik}

Analisa data secara statistik dilakukan melalui uji kecukupan data, uji presisi dan akurasi data, serta uji T. Hal ini digunakan untuk mengetahui apakah hipotesis yang telah dibuat dapat diterima atau tidak.

1. Uji Kecukupan Data

Data pengamatan dianggap cukup apabila $\mathrm{N}^{\prime}<\mathrm{N}$. 
$N^{\prime}=\left(\frac{k}{S} \frac{\sqrt{N \Sigma x^{2}-(\Sigma x)^{2}}}{\Sigma x}\right)^{2}$

Keterangan:

$\mathrm{N}^{\prime}=$ Jumlah pengamatan yang harus dilakukan

$\mathrm{k}=$ Tingkat kepercayaan dalam pengamatan $(\mathrm{k}=2$, $1-\alpha=95 \%)$

$\mathrm{S}=$ Derajat ketelitian dan pengamatan

$\mathrm{N}=$ Jumlah pengamatan yang sudah dilakukan

$\mathrm{X}=$ Kadar $\mathrm{N}$

(Purnomo, 2004)

2. Uji Presisi

Ketelitian yang baik adalah apabila nilai \%RSD < 2/3CV Horwitz.

$\% R S D=\frac{\sigma}{\bar{X}} \times 100 \%$

Keterangan:

RSD = Standar deviasi relatif

$\sigma \quad=$ Simpangan baku

$\overline{\mathrm{X}} \quad=$ Rata-rata kadar $\mathrm{N}$

CV Horwitz $=2^{1-0,5 \log c}$

dengan:

$c=\frac{\sigma}{100}=$ fraksi kadar 
3. Uji Akurasi

Upper Control Line $(\mathrm{UCL})=\bar{X}+3 \sigma$

Lower Control Line (LCL) $=\bar{X}-3 \sigma$

(Rosidi $d k k, 2011$ ).

dengan:

$\sigma=\sqrt{\frac{\sum(X-\bar{X})^{2}}{N-1}}$

Keterangan:

$\sigma$ = Simpangan baku

$\mathrm{X}=$ Kadar $\mathrm{N}$

$\overline{\mathrm{X}}=$ Rata-rata kadar $\mathrm{N}$

$\mathrm{N}$ = Jumlah data pengamatan

Data dianggap seragam jika semua sampel data berada pada cakupan range antara batas atas (UWL) dan batas bawah (LWL) (Tuning dan Samin, 2012).

4. Uji T

Jika $\mathrm{T}_{\text {hitung }}<\mathrm{T}_{\text {tabel }}$ maka $\mathrm{H}_{0}$ diterima dan $\mathrm{H}_{1}$ ditolak, dan jika $\mathrm{T}_{\text {hitung }}>\mathrm{T}_{\text {tabel }}$ maka $\mathrm{H}_{0}$ ditolak dan $\mathrm{H}_{1}$ diterima (Santoso, 2018).

$$
T_{\text {hitung }}=\frac{\bar{X}_{1}-\bar{X}_{2}}{S_{\text {gabungan }}\left(\sqrt{\frac{1}{N_{1}}}+\sqrt{\frac{1}{N_{2}}}\right)}
$$

Keterangan:

$\overline{\mathrm{X}}_{1} \quad=$ Rata-rata kadar N metode in house 


$$
\begin{aligned}
& \overline{\mathrm{X}}_{2}=\text { Rata-rata kadar N metode SNI-Inovasi } \\
& \mathrm{N}_{1}=\text { Jumlah pengamatan metode } \text { in house } \\
& \mathrm{N}_{2}=\text { Jumlah pengamatan metode SNI-Inovasi } \\
& \text { Sgab= Standar deviasi gabungan }
\end{aligned}
$$




\section{BAB IV}

\section{HASIL DAN PEMBAHASAN}

\section{A. Uji Kadar $\mathrm{H}_{2} \mathrm{O}$}

Uji kadar $\mathrm{H}_{2} \mathrm{O}$ dilakukan dengan menggunakan metode Karl Fischer Titration. Analisa kadar N pada pupuk NPK Reaksi dihitung dalam bentuk ADBK (Atas Dasar Berat Kering) dan ADBB (Atas Dasar Berat Basah), ADBK itu sendiri didapatkan ketika nilai kadar $\mathrm{H}_{2} \mathrm{O}$ sudah diperhitungkan dengan menggunakan metode Karl Fischer Titration. Hasil uji kadar $\mathrm{H}_{2} \mathrm{O}$ ditunjukkan pada tabel 4.1:

\begin{tabular}{ccc} 
Tabel 4.1 Hasil Uji Kadar $\mathbf{H}_{\mathbf{2}} \mathbf{O}$ \\
\hline $\begin{array}{c}\text { Bobot } \\
\text { Sampel } \\
\text { (g) }\end{array}$ & $\begin{array}{c}\text { Volume } \\
\text { Penitran } \\
\text { (mL) }\end{array}$ & $\begin{array}{c}\text { Kadar } \\
\mathbf{H}_{\mathbf{2}} \mathbf{O} \\
\mathbf{( \% )}\end{array}$ \\
\hline 0.2762 & 0.5580 & 1.36 \\
0.3027 & 0.6050 & 0.88 \\
0.3847 & 0.7580 & 0.87 \\
0.1762 & 0.4340 & 1.06 \\
0.1193 & 0.2790 & 1.01 \\
0.1681 & 0.4970 & 1.28 \\
0.1384 & 0.3890 & 1.21 \\
\hline
\end{tabular}

Hasil kadar $\mathrm{H}_{2} \mathrm{O}$ menggambarkan bahwa kadar $\mathrm{H}_{2} \mathrm{O}$ bisa dikatakan nilai yang fluktuatif, dikarenakan sampel yang dipakai bersifat hidrofilik. Oleh karena itu, faktor penyimpanan sampel berpengaruh terhadap kadar $\mathrm{H}_{2} \mathrm{O}$ pupuk NPK Reaksi (Dinas Pertanian, 2018). 


\section{B. Kadar N Pupuk NPK Reaksi}

Kadar N pada pupuk NPK Reaksi dengan metode in house dan metode SNI-Inovasi ditunjukkan pada tabel 4.2:

\section{Tabel 4.2 Hasil Uji Kadar N Pada Pupuk NPK Reaksi}

\begin{tabular}{|c|c|c|c|}
\hline \multicolumn{2}{|c|}{ Metode in house } & \multicolumn{2}{|c|}{ Metode SNI-Inovasi } \\
\hline $\begin{array}{c}\%(b / b) \\
\text { ADBB }\end{array}$ & $\begin{array}{l}\%(b / b) \\
\text { ADBK }\end{array}$ & $\begin{array}{l}\%(b / b) \\
\text { ADBB }\end{array}$ & $\begin{array}{l}\%(b / b) \\
\text { ADBK }\end{array}$ \\
\hline 14.06663 & 14.26058 & 15.60067 & 15.73918 \\
\hline 14.00406 & 14.19715 & 16.08388 & 16.22667 \\
\hline 13.88195 & 14.07335 & 15.34091 & 15.4771 \\
\hline 14.52764 & 14.72794 & 15.50804 & 15.64572 \\
\hline 14.19448 & 14.39019 & 14.26099 & 14.3876 \\
\hline 13.83936 & 14.03017 & 14.5774 & 14.70534 \\
\hline 14.04385 & 14.23748 & 15.64865 & 15.78599 \\
\hline 14.43978 & 14.63887 & 14.81558 & 14.94561 \\
\hline 14.8858 & 15.09103 & 15.7017 & 15.8395 \\
\hline 14.69531 & 14.89792 & 15.2383 & 15.37204 \\
\hline 14.65442 & 14.85647 & 15.37936 & 15.54413 \\
\hline 14.68709 & 14.88959 & 14.55167 & 14.71212 \\
\hline 13.80675 & 15.48131 & 15.1047 & 15.26653 \\
\hline 15.11789 & 15.32633 & 14.95768 & 15.11793 \\
\hline 14.99217 & 15.19887 & 14.73526 & 14.8856 \\
\hline 14.80727 & 15.01143 & 16.33744 & 16.50413 \\
\hline 14.93707 & 15.14301 & 15.90493 & 16.06721 \\
\hline 15.03819 & 15.24553 & 16.58187 & 16.75106 \\
\hline 14.95425 & 15.16043 & 14.34894 & 14.49535 \\
\hline 15.03705 & 15.24438 & 15.83051 & 16.03576 \\
\hline 14.64044 & 14.8423 & 14.7066 & 14.89729 \\
\hline 15.13155 & 15.34017 & 14.92209 & 15.11557 \\
\hline 15.0349 & 15.24219 & 15.00397 & 15.19851 \\
\hline 15.42391 & 15.63657 & 14.92904 & 15.12261 \\
\hline 14.62406 & 14.82569 & 15.28518 & 15.4724 \\
\hline
\end{tabular}


Metode in house

\begin{tabular}{cccc}
\hline $\begin{array}{c}\text { \% (b/b) } \\
\text { ADBB }\end{array}$ & $\begin{array}{c}\text { \% (b/b) } \\
\text { ADBK }\end{array}$ & $\begin{array}{c}\text { \% (b/b) } \\
\text { ADBB }\end{array}$ & $\begin{array}{c}\text { \% (b/b) } \\
\text { ADBK }\end{array}$ \\
\hline 14.71886 & 14.92179 & 14.34672 & 14.52244 \\
14.82769 & 15.03212 & 15.51401 & 15.70403 \\
14.89851 & 15.10392 & 15.75835 & 15.95136 \\
14.40903 & 14.60769 & 15.1386 & 15.32402 \\
Rata-rata ADBK= & Rata-rata ADBK= \\
$14.8551 \% \mathrm{~b} / \mathrm{b}$ & \multicolumn{2}{c}{$15.386 \% \mathrm{~b} / \mathrm{b}$} \\
\hline
\end{tabular}

C. Uji Statistik

Data dalam penelitian ini diambil sebanyak 30 kali pengulangan pada setiap metode. Uji kecukupan data yang digunakan dibuktikan dengan analisa secara statistik, dimana hasil perhitungan menunjukkan bahwa nilai $\mathrm{N}^{\prime}<\mathrm{N}$ maka data yang telah diambil dianggap sudah cukup dan tidak perlu melakukan pengambilan data kembali.

Uji presisi dilakukan dengan tujuan untuk mengetahui kedekatan nilai pengulangan yang telah diperoleh, ketelitian yang baik adalah apabila nilai \%RSD < nilai 2/3CV Horwitz (Sumardi, 2001). Hasil perhitungan uji presisi kedua metode menunjukkan bahwa \%RSD > nilai 2/3CV Horwitz yaitu 3.04\%b/b > $0.883 \% \mathrm{~b} / \mathrm{b}$ dan 4\%b/b > 1.7667\%b/b, dikarenakan perolehan data dalam kedua metode menunjukkan nilai yang fluktuatif sehingga tingkat presisi yang 
didapat juga rendah. Keberterimaan presisi adalah apabila nilai \%RSD < nilai 2/3CV Horwitz (Friscylia dkk, 2019), artinya presisi data yang telah didapatkan belum terpenuhi dan menunjukkan bahwa data tersebut memiliki ketelitian yang kurang baik.

Uji akurasi dihitung dengan tujuan guna mengetahui derajat kedekatan antar kadar hasil analisis pada tiap pengulangan dengan rerata data secara keseluruhan (Hajar, 2020). Uji akurasi dihitung berdasarkan upper and lower control levels (CL). Hasil pengujian akurasi data dapat dilihat pada Gambar 4.1 dan 4.2:

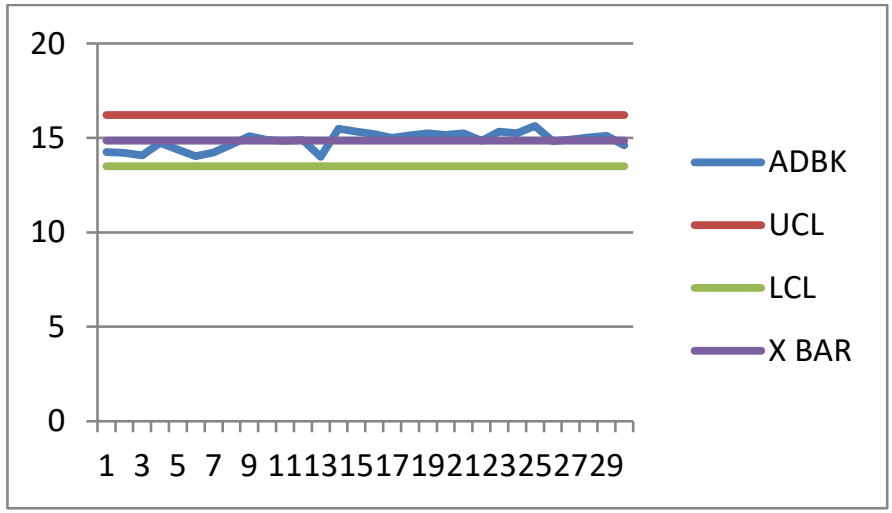

Gambar 4.1 Grafik Kontrol Hasil Uji Akurasi pada Metode in house 


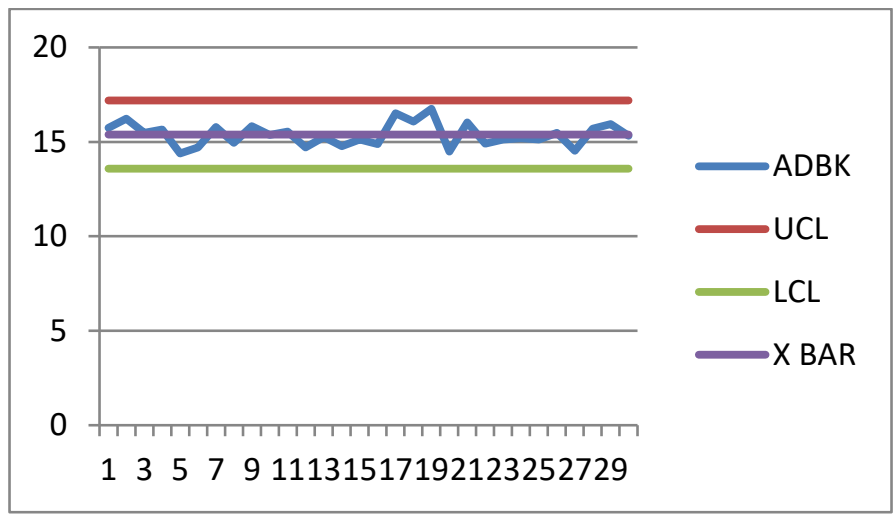

\section{Gambar 4.2 Grafik Kontrol Hasil Uji Akurasi pada Metode SNI-Inovasi}

Gambar 4.1 dan 4.2 menunjukkan bahwa titiktitik data pada tiap pengulangannya tidak ada yang melewati batas CL, artinya seluruh data yang didapatkan itu masuk pada rentang akurasi yang diperoleh. Hal yang demikian menandakan data yang diperoleh dapat diterima dan memiliki tingkat akurasi yang baik.

Uji T adalah uji signifikansi koefisien regresi yang dapat menunjukkan berpengaruh atau tidaknya satu variabel independen secara individual dalam menjelaskan variabel dependen (Haslinda dan Muhammad, 2016). Penggambaran uji T yang dapat diambil adalah tolak $\mathrm{H}_{0}$ jika $\mathrm{T}_{\text {hitung }} \geq \mathrm{T}_{\text {tabel }}$ dan tolak $\mathrm{H}_{1}$ jika $\mathrm{T}_{\text {hitung }}<\mathrm{T}_{\text {tabel }}$ (Santoso, 2018). Hasil perhitungan analisis uji $\mathrm{T}$ didapatkan nilai $\mathrm{T}_{\text {hitung }}$ sebesar -2.004 
sedangkan $\mathrm{T}_{\text {tabel }}$ sebesar 2.042, hal ini menunjukkan bahwa $\mathrm{H}_{1}$ ditolak dan $\mathrm{H}_{0}$ diterima. Artinya, secara signifikan hasil pengujian penggunaan kedua matode baik metode in house dan SNI-Inovasi tidak berbeda nyata. Hasil uji $\mathrm{T}$ membuktikan bahwa $\mathrm{H}_{0}$ diterima, artinya metode SNI-Inovasi bisa direkomendasikan sebagai metode analisa pada penetapan kadar nitrogen dalam pupuk NPK Reaksi di PT. Petrokimia Gresik. 


\section{BAB V \\ PENUTUP}

\section{A. Kesimpulan}

Rerata kadar nitrogen dalam pupuk NPK Reaksi menggunakan metode in house dan SNI-Inovasi yaitu sebesar 14.8551\%b/b dan 15.386\%b/b. Hasil uji statistik membuktikan bahwa metode in house dan SNI-Inovasi tidak berbeda nyata secara signifikan. Oleh karena itu, metode SNI-Inovasi bisa direkomendasikan sebagai metode analisa pada penetapan kadar nitrogen dalam pupuk NPK Reaksi di PT. Petrokimia Gresik.

\section{B. Saran}

Perlu dilakukan uji lanjutan seperti uji validasi untuk mengetahui apakah metode SNI-Inovasi telah valid untuk ditetapkan dan digunakan dalam penetapan analisis kadar nitrogen $(\mathrm{N})$ pupuk NPK Reaksi di PT. Petrokimia Gresik. 


\section{DAFTAR PUSTAKA}

Afif, M. (2015) Pengaruh Dosis Pupuk NPK Terhadap Pertumbuhan dan Hasil Produksi Tanaman Bayam ( Amaranthus spp ). Universitas Teuku Umar. Available at: http://repository.utu.ac.id/118/1/I-V.pdf.

Amalia, D. and Fajri, R. (2020) 'Analisis Kadar Nitrogen Dalam Pupuk Urea Prill Dan Granule Menggunakan Metode Kjeldahl Di Pt Pupuk Iskandar Muda', QUIMICA: Jurnal Kimia Sains dan Terapan, 2(1), pp. 28-32. doi: 10.33059/jq.v2i1.2639.

Badan Standardisasi Nasional (2012) Standar Nasional Indonesia 2803:2012 Pupuk NPK Padat. Jakarta: Badan Standardisasi Nasional.

Chang, R. (2005) Kimia Dasar Konsep-Konsep Inti Kimia Edisi Ketiga Jilid 2. Jakarta: Erlangga.

Daud, A., Suriati and Nuzulyanti (2019) 'Kajian Penerapan Faktor yang Mempengaruhi Akurasi Penentuan Kadar Air Metode Thermogravimetri', Lutjanus, 24(2), pp. 1116.

Dede Haryadi, Husna Yetti, S. Y. (2015) 'Pengaruh Pemberian Beberapa Jenis Pupuk Terhadap Pertumbuhan dan Produksi Tanaman Kailan (Brassica albogabra L.)', Jom Faperta, 2(2). doi: 10.15036/arerugi.44.821_2.

Dinas Pertanian (2018) Pupuk NPK Phonska, Fungsi Dan Manfaatnya Untuk Tanaman. Available at: https://bulelengkab.go.id/detail/artikel/pupuk-npkphonska-fungsi-dan-manfaatnya-untuk-tanaman-13 (Accessed: 29 September 2020).

Farida, N. Yudhi, Lilis. W, P. K. (2000) 'Studi Banding 
Penentuan Kadar H2O Dalam Serbuk UO2 Menggunakan Metode MEA (Moisture Evolution Analysis) Dan KFT (Karl Fischer Titration)', Prosiding Presentasi Ilmiah Daur Bahan Bakar Nuklir V P2TDBU \& P2BGN.

Friscylia, Koesnarpadi, S. and Panggabean, A. S. (2019) 'Verifikasi Metode Penentuan Timbal (Pb) Pada Pupuk NPK Menggunakan Atomic Absorption Spectrophotometer (AAS) Di PT Pupuk Kalimantan Timur', Jurnal Kimia FMIPA UNMUL, pp. 4-8.

Hajar, I. (2020) Uji Perbandingan Metode In House Dengan Metode Inovasi Penetapan Kadar Fosfor P205 Total Pada Pupuk NPK Reaksi Secara Spektrofotometri Sinar Tampak di PT Petrokimia Gresik. doi: 10.1017/CB09781107415324.004.

Harvey D (2000) Modern Analitycal Chemistry. USA: Mc Graw Hill Companies.

Hasibuan (2006) Ilmu Tanah. Medan: FP USU.

Haslinda and Muhammad, J. (2016) 'Pengaruh Perencanaan Anggaran Dan Evaluasi Anggaran Terhadap Kinerja Organisasi Dengan Standar Biaya Sebagai Variabel Moderating Pada Pemerintah Daerah Kabupaten Wajo', Jurnal Ilmiah Akuntansi Peradaban, 11(1), p. 10.

Kristianingrum, S. (2012) 'Kajian Berbagai Proses Destruksi Sampel dan Efeknya', Seminar Nasional Penelitian, Pendidikan dan Penerapan MIPA, 2(3), pp. 195-202.

Lingga, P. dan M. (2001) Petunjuk Penggunaan Pupuk. Jakarta: Penebar Swadaya.

Milis Y and Anjar PA (2019) 'Analisis Kadar Nitrogen Pada 
Pupuk Urea, Pupuk Cair Dan Pupuk Kompos Dengan Metode Kjeldahl ', 1(1), pp. 28-34.

PT Petrokimia Gresik (2019) Sejarah Perusahaan. Available at: https://petrokimia-gresik.com/page/sejarahperusahaan. (Accessed: 15 February 2020).

Purnomo, H. (2004) Pengantar Teknik Industri. Yogyakarta: Penerbit Graha Ilmu.

Rosidi et al. (2011) 'CONTROL CHART HASIL ANALISIS Zn DALAM SERUM SECARA AAN SEBAGAI PENGENDALI MUTU', pp. 278-281.

Sa, E. and Surya, A. (2010) 'Produk Air Minum dalam Kemasan Secara Laboratorium Penguji Baristand Air Minum dalam Kemasan Ini', 1(2), pp. 31-37.

Santoso, L. (2018) 'Analisis Pengaruh Price, Overall Satisfaction, Dan Trust Terhadap Intention to Return Pada Online Store Lazada', Agora, 6(1), p. 287262.

Simanjuntak, R. (2018) 'Penetapan Kadar Asam Lemak Bebas Pada Sabun Mandi Cair Merek "Lx" Dengan Metode Titrasi Asidimetri', Jurnal Ilmiah Kohesi, 2(4), pp. 59-70.

Sokhibi, A. (2017) 'PERANCANGAN KURSI ERGONOMIS UNTUK MEMPERBAIKI POSISI KERJA PADA PROSES PACKAGING JENANG KUDUS Akhmad Sokhibi Program Studi Teknik Industri, Fakultas Teknik, Universitas Muria Kudus Jl . Lingkar Utara Gondangmanis Bae Kudus Jawa Tengah 59327 Email : akh.', 3(1), pp. 61-72.

Sumardi (2001) Validasi Metode Analisis. Jakarta: Badan Standarisasi Nasional.

Suradi et al. (2015) 'Alat Distilasi Sederhana Berbasis Peralatan Rumah Tangga', Jurnal Pendidikan dan 
Pembelajaran Kimia, 4(3), pp. 1125-1136.

Tjahjaningsih, W., Widaratna, A. P. and Alamsjah, M. A. (2019) 'Pengaruh Kombinasi Pupuk NPK Dan TSP Terhadap Pertumbuhan, Kadar Air Dan Klorofil A Gracilaria verrucosa', Jurnal Ilmiah Perikanan dan Kelautan, 1(1), p. 103. doi: 10.20473/jipk.v1i1.11705.

Tuning, S. and Samin, S. (2012) 'PENGENDALIAN MUTU HASIL UJI UNSUR-UNSUR Ca DAN Mg DALAM AIR TANGKI REAKTOR DENGAN METODE AAS', Prosiding Pertemuan dan Presentasi Ilmiah - Penelitian Dasar Ilmu Pengetahuan dan Teknologi Nuklir, pp. 184-189.

Ulfa, A., Retnaningsih, A. and Aufa, R. (2017) 'Penetapan Kadar Asam Lemak Bebas Pada Minyak Kelapa, Minyak Kelapa Sawit Dan Minyak Zaitun Kemasan Secara Alkalimetri', Jurnal Analis Farmasi, 2(4), pp. 242-250.

Utami, A. R. (2017) 'Verifikasi Metode Pengujian Sulfat Dalam Air dan Air Limbah Sesuai SNI 6989.20 : 2009', Jurnal Teknologi Proses dan Inovasi Industri, 2(1). doi: 10.36048/jtpii.v2i1.2726.

Walangare, K. B. A. et al. (2013) 'Rancang Bangun Alat Konversi Air Laut Menjadi Air Minum Dengan Proses Destilasi Sederhana Menggunakan Pemanas Elektrik', $e$ Jurnal Teknik Elektrodan komputer.

Wiyantoko, B., Kurniawati, P. and Purbaningtias, T. E. (2017) 'Pengujian Nitrogen Total, Kandungan Air Dan Cemaran Logam Timbal Pada Pupuk Anorganik Npk Padat', JST (Jurnal Sains dan Teknologi), 6(1), pp. 51-60. doi: 10.23887/jst-undiksha.v6i1.9439. 


\section{RIWAYAT HIDUP}

\section{A. Identitas Diri}

1. Nama Lengkap

: Nida Awalia

2. Tempat \& Tgl. Lahir

: Tegal, 26 Maret 1999

3. Alamat Rumah

: Jl. Ali Imron no.46 RT 02 RW

01 Kertasari Suradadi Tegal

HP

: 0853-2669-5736

E-mail

:nidaamalia263@gmail.com

\section{B. Riwayat Pendidikan}

1. Pendidikan Formal:

a. MI NU 01 Kertasari 2005-2011

b. MTs NU 01 Suradadi 2011-2014

c. SMA Negeri 3 Pemalang 2014-2017

d. Kimia UIN Walisongo Semarang 2017-2021

2. Pendidikan Non-Formal:

a. TK/TPA MNU ASY-SYIFA Blendung Kertasari Suradadi Tegal 2005-2009

b. MDTA Kertasari Suradadi Tegal 2008-2012

c. MDW SALAFIYAH Kauman Pemalang 2014-2017

\section{Publikasi Ilmiah}

a. Analisis Kadar Nitrogen (N) dalam Pupuk NPK Reaksi PT. Petrokimia Gresik Menggunakan Metode in house dan SNI-Inovasi

Semarang, 25 Maret 2021

Nida Awalia NIM : 1708036013 


\title{
LAMPIRAN
}

\section{Lampiran 1 Artikel Ilmiah}

\section{ANALISIS KADAR NITROGEN (N) DALAM PUPUK NPK REAKSI PT. PETROKIMIA GRESIK MENGGUNAKAN METODE IN HOUSE DAN SNI-INOVASI}

Nida Awalia", dan Ika Nur Fitriani

Jurusan Kimia, Fakultas Sains dan Teknologi, UIN Walisongo Semarang Jl. Prof. Dr. Hamka, Tambakaji, Kec. Ngaliyan, Kota Semarang, Jawa Tengah 50185. "Email: nidaawalia99@gmail.com

\begin{abstract}
Abstrak
Uji kadar nitrogen dilakukan untuk mengetahui kadar nitrogen pada pupuk NPK Reaksi hasil produksi pabrik II PT Petrokimia Gresik. Pengujian kadar nitrogen pada penelitian ini menggunakan dua metode yaitu metode in house dan metode SNI-Inovasi mengenai pupuk NPK Reaksi yang juga digunakan sebagai acuan standar hasil pengujian. Metode SNI-Inovasi dilakukan untuk mengetahui ada atau tidaknya reagen lain yang bisa digunakan untuk analisis kadar $N$ selain reagen yang biasa digunakan pada metode in house. Kedua metode tersebut menggunakan prinsip dasar metode kjeldahl yang melalui tiga tahapan yaitu destruksi, destilasi, dan titrasi. Parameter statistik yang dianalisa pada penelitian ini diantaranya adalah uji kecukupan data, uji presisi dan akurasi data, serta uji T. Rata-rata kadar nitrogen pupuk NPK Reaksi menggunakan metode in house dan SNI-Inovasi berturut-turut sebesar $14.8551 \% \mathrm{~b} / \mathrm{b}$ dan $15.386 \% \mathrm{~b} / \mathrm{b}$. Hasil uji statistik menunjukkan bahwa metode in house dan SNI-Inovasi tidak berbeda nyata secara signifikan sehingga metode SNI-inovasi dapat direkomendasikan sebagai metode analisa dalam penetapan kadar nitrogen pada pupuk NPK Reaksi di PT. Petrokimia Gresik.
\end{abstract}

Kata kunci: metode in house, metode SNI-Inovasi, kadar N, pupuk NPK Reaksi

\section{PENDAHULUAN}

PT. Petrokimia Gresik adalah salah satu anak perusahaan dari BUMN PT. Pupuk Indonesia (Persero) yang memiliki dua kategori produk yaitu pupuk dan non pupuk serta bahanbahan kimia untuk keperluan industri. Salah satu produk kategori pupuk yang dihasilkan oleh perusahaan ini adalah pupuk NPK Reaksi (PT Petrokimia Gresik, 2019). Pupuk NPK Reaksi dibuat dengan menggunakan proses reaksi antara ammoniak dengan asam fosfat sebagai bahan dasar dari unsur $\mathrm{N}$ dan $\mathrm{P}$. Unsurunsur yang terkandung dalam pupuk NPK Reaksi adalah nitrogen, fosfor, dan kalium.

Nitrogen (N) adalah unsur hara yang memiliki peran penting dalam pembentukan dan merangsang pertumbuhan tanaman secara keseluruhan tetapi jika jumlahnya berlebihan maka dapat menghambat pembuahan dan pembungaan suatu tanaman (Wiyantoko dkk, 2017). Jumlah nitrogen yang tinggi sangat berpengaruh terhadap pertumbuhan berat maupun panjang suatu tanaman (Wahyu Tjahjaningsih dan Anugraheny Widaratna Pratiwi, 2019)

Pengujian kadar $\mathrm{N}$ dalam pupuk NPK Reaksi dilakukan dengan menggunakan metode in house dan metode SNI-Inovasi, kedua metode ini berprinsip dasar metode kjeldahl yang terdiri dari tahap destruksi, destilasi, dan titrasi (Milis Y dan Anjar PA, 2019). Analisis kadar $\mathrm{H}_{2} \mathrm{O}$ pada pupuk NPK Reaksi dilakukan dengan menggunakan Karl Fischer Titration.

Metode in house adalah metode rutin yang digunakan di PT. Petrokimia Gresik dengan mengacu pada SNI (Standar Nasional Indonesia) dan ASTM (American Society for Testing and Material) sedangkan metode SNIInovasi adalah metode in house yang kemudian dikembangkan sebagai alternatif lain untuk meningkatkan keefisienan dan keefektifan dalam proses analisis, sehingga dilakukanlah analisa kadar N pada pupuk NPK Reaksi di PT. Petrokimia Gresik dengan menggunakan kedua metode tersebut.

Pengembangan atau perubahan pada metode SNI-Inovasi terletak pada reagen yang digunakan dan hasil destruksi sampel yang kemudian didinginkan, dimasukkan ke dalam labu takar $500 \mathrm{~mL}$ dan ditambahkan akuades hingga tanda tera. Parameter statistik yang dianalisa pada penelitian ini adalah uji kecukupan data, uji presisi dan akurasi data, serta uji T. Parameter statistik ini digunakan untuk mengetahui dan membuktikan apakah suatu hipotesis yang kita buat dapat diterima atau tidak.

Metode SNI-Inovasi digunakan dalam rangka mencoba mencari alternatif lain untuk meningkatkan segi keefisienan maupun 
keefektifan dalam proses analisis, sehingga dilakukanlah analisis kadar $\mathrm{N}$ dengan menggunakan dua metode untuk mengetahui ada atau tidaknya perbedaan yang signifikan antara metode in house dan metode SNI-inovasi pada penetapan kadar $\mathrm{N}$ dalam pupuk NPK Reaksi di PT.

Petrokimia Gresik dan dapatkah metode SNI-Inovasi dijadikan sebagai rekomendasi metode analisa dalam penetapan kadar nitrogen pada pupuk NPK Reaksi di PT. Petrokimia Gresik. Peningkatan segi keefisienan dan keefektifan terjadi karena dengan menggunakan metode SNI-Inovasi akan menghasilkan produk yang sesuai dengan Standar Nasional Indonesia (SNI) 2803 tahun 2012 tentang pupuk NPK Reaksi. Hal ini juga dapat meningkatkan kepercayaan bagi konsumen bahwa pupuk NPK yang dihasilkan PT. Petrokimia Gresik itu berkualitas.

\section{METODOLOGI}

Penelitian ini dilakukan untuk mengetahui kadar N pada pupuk NPK Reaksi hasil produksi pabrik II PT. Petrokimia Gresik dengan menggunakan metode in house dan SNI-Inovasi yang berprinsip dasar metode Kjeldahl .

\subsection{Alat}

Alat yang digunakan dalam penelitian ini adalah spatula, neraca analitik, labu kjeldahl, alat destruksi, alat destilasi vapodest, erlenmeyer, buret, labu ukur $500 \mathrm{~mL}$, dan pipet volume.

\subsection{Bahan}

Bahan yang digunakan dalam penelitian ini adalah sampel produk pupuk NPK Reaksi, akuades, $\mathrm{H}_{2} \mathrm{SO}_{4} 98 \%, \mathrm{H}_{2} \mathrm{SO}_{4} 0.5 \mathrm{~N}, \mathrm{H}_{2} \mathrm{SO}_{4} 0.05$ $\mathrm{N}, \mathrm{NaOH} 0.25 \mathrm{~N}, \mathrm{H}_{3} \mathrm{BO}_{3} 1 \%$, indikator mix acid, indikator conway, dan indikator PP.

\subsection{Cara Kerja}

Tahap destruksi diawali dengan penimbangan sampel \pm 0.8 gram untuk metode in house dan \pm 0.5 gram untuk metode SNIInovasi, kemudian alat destruksi dipanaskan dan sampel dalam labu kjeldahl diberi sedikit akuades serta $\mathrm{H}_{2} \mathrm{SO}_{4} 98 \%$ sebanyak $25 \mathrm{~mL}$. Tahap destruksi metode SNI-Inovasi dilanjutkan dengan pendinginan dan penambahan akuades hingga tera dalam labu ukur $500 \mathrm{~mL}$, kemudian dihomogenkan dengan menggunakan magnetic stirrer dan diambil 25 $\mathrm{mL}$ menggunakan pipet volume dan dimasukkan kembali ke dalam labu kjeldahl. Proses dilanjutkan dengan pemberian indikator PP dalam labu kjeldahl pada kedua metode.
Tahap destilasi diawali dengan pembuatan penjerap yaitu $\mathrm{H}_{2} \mathrm{SO}_{4} 0.5 \mathrm{~N} 25 \mathrm{~mL}$ dengan indikator mix acid dalam erlenmeyer pada metode in house dan $\mathrm{H}_{3} \mathrm{BO}_{3} \quad 1 \% 25 \mathrm{~mL}$ dengan indikator conway dalam erlenmeyer untuk metode SNI-Inovasi. Sampel dalam labu kjeldahl dimasukkan ke dalam alat destilasi vapodest dan didestilasi hingga beberapa menit, sehingga dihasilkanlah destilat.

Tahap titrasi diawali dengan pembuatan titran yaitu $\mathrm{NaOH} 0.25 \mathrm{~N}$ untuk metode in house dan $\mathrm{H}_{2} \mathrm{SO}_{4} 0.05 \mathrm{~N}$ untuk metode SNIInovasi. Destilat yang dihasilkan kemudian dititrasi dengan masing-masing titran untuk diketahui konsentrasi nitrogen $(\% \mathrm{~N})$ pada sampel pupuk NPK Reaksi. Persentase nitrogen dihitung dengan menggunakan rumus:

Metode in house

$\% N=\frac{\left(\mathrm{N}_{2} \mathrm{SO}_{4} \times V_{\mathrm{H}_{2} \mathrm{SO}_{4}}\right)-\left(\mathrm{N}_{\mathrm{NaOH}} \times V_{\mathrm{NaOH}}\right) \times 14 \times 100}{\text { bobot penimbangan }} F$

Metode SNI-Inovasi

$\% \mathrm{~N}=\frac{V_{P} X N_{P} X A r N X F p}{\text { bobot sampel }(\mathrm{mg})} 100 \%$

Rangkaian alat tahapan metode kjeldahl ditunjukkan pada gambar 1:
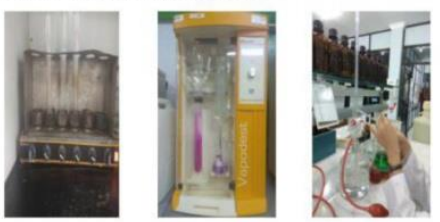

\section{Gambar 1. Rangkaian Alat Tahapan Metode} Kjeldahl

Pengukuran kadar $\mathrm{H}_{2} \mathrm{O}$ pada pupuk NPK Reaksi dilakukan dengan menggunakan metode Karl Fischer Titration. Titrasi akan berjalan setelah ditekan tombol start pada Karl Fischer dan akan berakhir otomatis jika telah mencapai titik akhir. Metode Karl Fischer Titration (KFT) menggunakan larutan hidranal yang memiliki kemampuan untuk menganalisis kadar $\mathrm{H}_{2} \mathrm{O}$ dalam sampel yang berbentuk cairan maupun padatan (Farida dkk, 2000). Rangkaian alat karl fischer ditunjukkan pada gambar 2: 


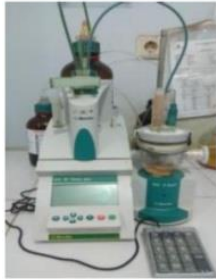

\section{Gambar 2. Alat Karl Fischer}

\subsection{Pengujian Statistik}

Analisa data secara statistik dilakukan dengan menggunakan uji kecukupan data, uji presisi dan akurasi data, serta uji T. Hal ini digunakan untuk mengetahui apakah suatu hipotesis dapat diterima atau tidak.

Hipotesis nol $\left(\mathrm{H}_{0}\right)$ : Rerata hasil pengujian metode in house dan metode SNI-inovasi tidak berbeda nyata secara signifikan.

Hipotesis alternatif $\left(\mathrm{H}_{1}\right)$ : Rerata hasil pengujian in house dan metode SNI-Inovasi berbeda nyata secara signifikan.

\section{Uji Kecukupan Data}

Data pengamatan dianggap cukup apabila $\mathrm{N}^{\prime}<\mathrm{N}$.

$$
N^{\prime}=\left(\frac{K}{S} \frac{\sqrt{N \Sigma x^{2}-\left(\Sigma x^{2}\right)}}{\Sigma x}\right)^{2}
$$

\section{Uji Presisi}

Ketelitian yang baik adalah apabila nilai $\%$ RSD $<2 / 3$ CV Horwitz.

$$
\begin{aligned}
& \% R S D=\frac{\sigma}{\bar{x}} \times 100 \% \\
& \text { CV Horwitz }=2^{1-0,5 \log c}
\end{aligned}
$$

dengan:

$$
c=\frac{\sigma}{100}=\text { fraksi kadar }
$$

\section{Uji Akurasi}

Upper Warning Line $(\mathrm{UWL})=\mathrm{X}+\mathrm{K} .2 \sigma$

Lower Warning Line $(\mathrm{LWL})=\mathrm{X}-\mathrm{K} .2 \sigma$

dengan:

$$
\sigma=\sqrt{\frac{\Sigma(X-\bar{X})^{2}}{N-1}}
$$

Data akan dianggap seragam apabila seluruh sampel data berada dalam cakupan range antara batas bawah (LWL) dan batas atas (UWL) (Tuning dan Samin, 2012).

\section{Uji T}

Jika $\mathrm{T}_{\text {hitung }}<\mathrm{T}_{\text {tabel }}$ maka $\mathrm{H}_{0}$ diterima dan $\mathrm{H}_{1}$ ditolak, dan jika $\mathrm{T}_{\text {hitung }}>\mathrm{T}_{\text {tabel }}$ maka $\mathrm{H}_{0}$ ditolak dan $\mathrm{H}_{1}$ diterima (Santoso, 2018).

$$
T_{\text {hitung }}=\frac{\bar{X}_{1}-\bar{X}_{2}}{S_{\text {gabungan }}\left(\sqrt{\frac{1}{N_{2}}}+\sqrt{\frac{1}{N_{2}}}\right)}
$$

\section{HASIL DAN PEMBAHASAN}

Uji kadar $\mathrm{H}_{2} \mathrm{O}$ dilakukan dengan menggunakan metode Karl Fischer Titration. Analisa kadar N dalam pupuk NPK Reaksi dihitung dalam bentuk ADBB (Atas Dasar Berat Basah) dan ADBK (Atas Dasar Berat Kering), dimana ADBK itu dihitung ketika sudah mendapatkan nilai kadar $\mathrm{H}_{2} \mathrm{O}$ dengan menggunakan metode Karl Fischer Titration. Hasil uji kadar $\mathrm{H}_{2} \mathrm{O}$ ditunjukkan pada tabel 1 :

\begin{tabular}{ccc}
\multicolumn{2}{c}{ Tabel 1. Hasil Uji Kadar $\mathrm{H}_{2} \mathbf{O}$} \\
\hline $\begin{array}{c}\text { Bobot } \\
\text { Sampel } \\
(\mathrm{g})\end{array}$ & $\begin{array}{c}\text { Volume } \\
\text { Penitran } \\
(\mathbf{m L})\end{array}$ & $\begin{array}{c}\text { Kadar } \\
\mathbf{H}_{2} \mathbf{O}(\%)\end{array}$ \\
\hline 0.2762 & 0.5580 & 1.36 \\
0.3027 & 0.6050 & 0.88 \\
0.3847 & 0.7580 & 0.87 \\
0.1762 & 0.4340 & 1.06 \\
0.1193 & 0.2790 & 1.01 \\
0.1681 & 0.4970 & 1.28 \\
0.1384 & 0.3890 & 1.21 \\
\hline & &
\end{tabular}

Hasil kadar $\mathrm{H}_{2} \mathrm{O}$ menunjukkan bahwa kadar $\mathrm{H}_{2} \mathrm{O}$ dapat dikatakan sebagai nilai yang fluktuatif. Hal ini dikarenakan sampel yang digunakan bersifat hidrofilik, sehingga faktor penyimpanan sampel sangat berpengaruh (Dinas Pertanian, 2018).

Hasil Pengukuran Kadar N Pada Pupuk NPK Reaksi dengan Metode in house dan Metode SNI-Inovasi ditunjukkan pada tabel 2: 
Tabel 2. Hasil Uji Kadar N pada Pupuk NPK Reaksi

\begin{tabular}{|c|c|c|c|}
\hline \multicolumn{2}{|c|}{ Metode in house } & \multicolumn{2}{|c|}{ Metode SNI-Inovasi } \\
\hline$\%(b / b)$ & $\%(b / b)$ & $\%(b / b)$ & $\%(\mathbf{b} / \mathbf{b})$ \\
\hline ADBB & ADBK & ADBB & ADBK \\
\hline 14.06663 & 14.26058 & 15.60067 & 15.73918 \\
\hline 14.00406 & 14.19715 & 16.08388 & 16.22667 \\
\hline 13.88195 & 14.07335 & 15.34091 & 15.4771 \\
\hline 14.52764 & 14.72794 & 15.50804 & 15.64572 \\
\hline 14.19448 & 14.39019 & 14.26099 & \\
\hline 13.83936 & 14.03017 & 14.5774 & 14.70534 \\
\hline 14.0438 & 14.23748 & 15.64865 & \\
\hline 14.4397 & 14.63887 & 14.8 & 14.94561 \\
\hline 14.8858 & $15.6(-2) \cdot(x)$ & 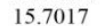 & \\
\hline 14.69531 & 14.8 & 3 & 7204 \\
\hline 14.65442 & 14.8 & 15.37 & \\
\hline 14.68709 & 14.88959 & 14.55 & 1212 \\
\hline 13.80675 & 15.48131 & 15.1 & 6653 \\
\hline 15.11789 & 2633 & 14.9 & 15.11793 \\
\hline 14.99217 & 9887 & 14.7 & 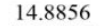 \\
\hline 14.80727 & 15.01143 & 16.33744 & 16.50413 \\
\hline 14.93707 & 15.14301 & 15.90493 & 16.06721 \\
\hline 15.03819 & 15.24553 & 16.58187 & 16.75106 \\
\hline 14.95425 & 15.16043 & 14.34894 & 14.49535 \\
\hline 15.03705 & 15.24438 & 15.83051 & 16.03576 \\
\hline 14.64044 & 14.8423 & 14.7066 & 14.89729 \\
\hline 15.13155 & 15.34017 & 14.92209 & 15.11557 \\
\hline 15.0349 & 15.24219 & 15.00397 & 15.19851 \\
\hline 15.42391 & 15.63657 & 14.92904 & 15.12261 \\
\hline 14.62406 & 14.82569 & 15.28518 & 15.4724 \\
\hline 14.71886 & 14.92179 & 14.34672 & 14.52244 \\
\hline 14.82769 & 15.03212 & 15.51401 & 15.70403 \\
\hline 14.89851 & 15.10392 & 15.75835 & 15.95136 \\
\hline 14.40903 & 14.60769 & 15.1386 & 15.32402 \\
\hline \multicolumn{2}{|c|}{ Rata-rata $\mathrm{ADBK}=$} & \multicolumn{2}{|c|}{ Rata-rata $\mathrm{ADBK}=$} \\
\hline \multicolumn{2}{|c|}{$14.8551 \% \mathrm{~b} / \mathrm{b}$} & \multicolumn{2}{|c|}{$15.386 \% \mathrm{~b} / \mathrm{b}$} \\
\hline
\end{tabular}

Pengambilan data dalam penelitian ini adalah 30 kali pengulangan pada setiap metode. Uji kecukupan data yang digunakan dibuktikan dengan analisa secara statistik, dimana hasil perhitungan menunjukkan bahwa nilai $\mathrm{N}^{\prime}<\mathrm{N}$ maka data yang telah diambil dianggap sudah cukup dan tidak perlu melakukan pengambilan data kembali.

Uji presisi dilakukan dengan tujuan untuk mengetahui kedekatan nilai pengulangan yang telah diperoleh, ketelitian yang baik adalah apabila nilai $\%$ RSD $<$ nilai $2 / 3 \mathrm{CV}$ Horwitz (Sumardi, 2001). Hasil perhitungan uji presisi kedua metode menunjukkan bahwa \%RSD > nilai 2/3CV Horwitz yaitu $3.04 \% \mathrm{~b} / \mathrm{b}>$ $0.883 \% \mathrm{~b} / \mathrm{b}$ dan $4 \% \mathrm{~b} / \mathrm{b}>1.7667 \% \mathrm{~b} / \mathrm{b}$, hal ini dimungkinkan karena perolehan data pada kedua metode cenderung fluktuatif sehingga tingkat presisinya rendah. Syarat keberterimaan presisi adalah nilai \%RSD $<$ nilai $2 / 3 \mathrm{CV}$ Horwitz (Friscylia dkk, 2019), artinya presisi data yang telah didapatkan belum terpenuhi dan menunjukkan bahwa data tersebut memiliki ketelitian yang kurang baik.

Uji akurasi dilakukan dengan tujuan untuk mengetahui derajat kedekatan antar kadar hasil analisis sampel pada tiap pengulangan dengan rata-rata keseluruhan data (Hajar, 2020). Uji akurasi diperhitungkan dengan menggunakan upper and lower warning levels (WL) dan upper and lower control levels (CL). Hasil pengujian akurasi data dapat dilihat pada Gambar 3 dan 4:

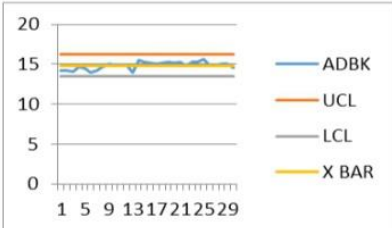

Gambar 3. Grafik Kontrol Hasil Uji Akurasi pada Metode in house

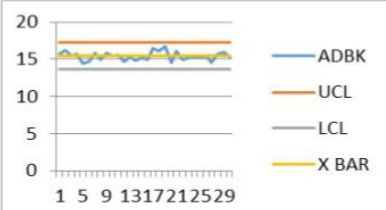

Gambar 4. Grafik Kontrol Hasil Uji Akurasi pada Metode SNI-Inovasi

Gambar 3 dan 4 menunjukkan bahwa titiktitik data pada tiap pengulangannya tidak ada yang melewati batas WL maupun CL, artinya seluruh data yang didapatkan itu masuk pada rentang akurasi yang diperoleh. Hal yang demikian menandakan data yang didapatkan memiliki tingkat akurasi yang baik.

Uji $\mathrm{T}$ adalah uji signifikansi koefisien regresi untuk menunjukkan berpengaruh atau tidaknya satu variabel independen secara individual dalam menerangkan variabel dependen (Haslinda dan Muhammad, 2016). Penggambaran uji $\mathrm{T}$ yang dapat diambil adalah tolak $\mathrm{H}_{0}$ jika $\mathrm{T}_{\text {hitung }} \geq \mathrm{T}_{\text {tabel }}$ dan tolak $\mathrm{H}_{1}$ jika $\mathrm{T}_{\text {hitung }}<\mathrm{T}_{\text {tabel }}$ (Santoso, 2018). Hasil perhitungan 
analisis uji $\mathrm{T}$ didapatkan nilai $\mathrm{T}_{\text {hitung }}$ sebesar 2.004 sedangkan $\mathrm{T}_{\text {tabel }}$ sebesar 2.042 , hal ini menunjukkan bahwa $\mathrm{H}_{1}$ ditolak dan $\mathrm{H}_{0}$ diterima. Artinya, hasil pengujian metode in house dan SNI-Inovasi tidak berbeda nyata secara signifikan. Penelitian dikatakan berhasil dan suatu hipotesis dapat diterima yang berarti secara parsial variabel independen tidak berpengaruh signifikan terhadap variabel dependen.

Hasil uji $\mathrm{T}$ menunjukkan bahwa $\mathrm{H}_{0}$ diterima, artinya metode SNI-Inovasi dapat direkomendasikan sebagai metode analisa dalam penetapan kadar nitrogen pada pupuk NPK Reaksi dengan syarat harus dilakukan uji lanjutan seperti uji validasi untuk mengetahui apakah metode SNI-Inovasi telah valid dan dapat digunakan di laboratorium II-B PT. Petrokimia Gresik.

\section{UCAPAN TERIMA KASIH}

Terima kasih kepada Bapak Abizar Rahman Hadi selaku Pembimbing Lapangan Kerja Praktik di Laboratorium Pabrik II-B, Departemen Proses dan Pengelolaan Energi, PT. Petrokimia Gresik.

\section{KESIMPULAN}

Rata-rata kadar nitrogen pada pupuk NPK Reaksi menggunakan metode in house dan SNIInovasi berturut-turut sebesar $14.8551 \% \mathrm{~b} / \mathrm{b}$ dan $15.386 \% \mathrm{~b} / \mathrm{b}$. Pengolahan data menggunakan uji statistik hasil metode in house dan SNI-Inovasi tidak berbeda nyata secara signifikan sehingga metode SNI-inovasi dapat direkomendasikan sebagai metode analisa dalam penetapan kadar nitrogen pada pupuk NPK Reaksi di PT Petrokimia Gresik.

\section{DAFTAR PUSTAKA}

Dinas Pertanian (2018). 'Pupuk NPK Phonska, Fungsi Dan Manfaatnya Untuk Tanaman'. Available https://bulelengkab.go.id/detail/artikel/pup uk-npk-phonska-fungsi-dan-manfaatnya untuk-tanaman-13

(Accessed: 29 September 2020).

Farida, N. Yudhi, Lilis. W, P. K. (2000) 'Studi Banding Penentuan Kadar $\mathrm{H}_{2} \mathrm{O}$ Dalam Serbuk $\mathrm{UO}_{2}$ Menggunakan Metode MEA (Moisture Evolution Analysis) Dan KFT (Karl Fischer Titration)', Prosiding Presentasi Ilmiah Daur Bahan Bakar Nuklir V P2TDBU \& P2BGN.

Friscylia, Koesnarpadi, S. and Panggabean, A.
S. (2019). 'Verifikasi Metode Penentuan Timbal (Pb) Pada Pupuk NPK Menggunakan Atomic Absorption Spectrophotometer (AAS) Di PT Pupuk Kalimantan Timur', Jurnal Kimia FMIPA UNMUL, pp. 4-8.

Hajar, I. (2020). 'Uji Perbandingan Metode In House Dengan Metode Inovasi Penetapan Kadar Fosfor $\mathrm{P}_{2} \mathrm{O}_{5}$ Total Pada Pupuk NPK Reaksi Secara Spektrofotometri Sinar Tampak di PT Petrokimia Gresik', doi: 10.1017/CBO9781107415324.004.

Haslinda and Muhammad, J. (2016) 'Pengaruh Perencanaan Anggaran Dan Evaluasi Anggaran Terhadap Kinerja Organisasi Dengan Standar Biaya Sebagai Variabel Moderating Pada Pemerintah Daerah Kabupaten Wajo', Jurnal Ilmiah Akuntansi Peradaban, 11(1), p. 10.

Milis Y and Anjar PA (2019) 'Analisis Kadar Nitrogen Pada Pupuk Urea, Pupuk Cair Dan Pupuk Kompos Dengan Metode Kjeldahl ', 1(1), pp. 28-34.

PT Petrokimia Gresik (2019). 'Sejarah Perusahaan'. Available at: https://petrokimiagresik.com/page/sejarah-perusahaan. (Accessed: 15 February 2020).

Santoso, L. (2018) 'Analisis Pengaruh Price, Overall Satisfaction, Dan Trust Terhadap Intention to Return Pada Online Store Lazada', Agora, 6(1), p. 287262.

Sumardi (2001). 'Validasi Metode Analisis'. Jakarta: Badan Standarisasi Nasional.

Tuning, S. and Samin, S. (2012) 'Pengendalian Mutu Hasil Uji Unsur-Unsur Ca Dan Mg Dalam Air Tangki Reaktor Dengan Metode AAS', Prosiding Pertemuan dan Presentasi Ilmiah - Penelitian Dasar Ilmu Pengetahuan dan Teknologi Nuklir, pp. 184-189.

Wahyu Tjahjaningsih, Anugraheny Widaratna Pratiwi, M. A. A. (2019) 'Pengaruh Kombinasi Pupuk NPK Dan TSP Terhadap Pertumbuhan, Kadar Air Dan Klorofil A Gracilaria verrucosa', Jurnal Ilmiah Perikanan dan Kelautan, 1(1), p. 103. doi: 10.20473/jipk.vlil.11705.

Wiyantoko, B., Kurniawati, P. and Purbaningtias, T. E. (2017). 'Pengujian Nitrogen Total, Kandungan Air Dan Cemaran Logam Timbal Pada Pupuk Anorganik NPK Padat', JST (Jurnal Sains dan Teknologi), 6(1), pp. 51-60. doi: $10.23887 /$ jst-undiksha.v6il.9439. 


\section{Lampiran 2 Perhitungan Analisa}

- Metode in house

Diketahui: $\mathrm{k}=2 \quad \Sigma \mathrm{X}^{2}=6626.1$

$$
\begin{array}{ll}
\mathrm{N}=30 & (\Sigma \mathrm{X})^{2}=198605 \\
\alpha=0.05 & \Sigma \mathrm{X}=445.652 \\
N^{\prime}=\left(\frac{k}{S} \frac{\sqrt{N \Sigma x^{2}-(\Sigma x)^{2}}}{\Sigma x}\right)^{2}
\end{array}
$$$$
=\left(\frac{2}{0.05} \frac{\sqrt{(30 X 6626.1)-198605}}{445.652}\right)^{2}
$$$$
=1.434 \approx 30 \text { data }
$$

- $\quad$ ADBK rata-rata $=\frac{445.652}{30}=14.8551$

- $\sigma=\sqrt{\frac{5.926}{29}}=0.452$

- $\quad \mathrm{UCL}=14.8551+(3 \mathrm{X} 0.452)=16.21124182$

- $\quad$ LCL $=14.8551-(3 X 0.452)=13.49895818$

- $\quad \% \mathrm{RSD}=\frac{0.452}{14.8551} \times 100 \%=3.04 \%$

- $\quad \% 2 / 3 \mathrm{CV}$ Horwitz $=2^{1-0.5 x \log ^{0.148551}}$

- Metode SNI-Inovasi

$$
=0,883 \% \mathrm{~b} / \mathrm{b}
$$

Diketahui: $\mathrm{k}=2$

$$
\begin{aligned}
& \mathrm{N}=30 \quad(\Sigma X)^{2}=213067 \\
& \alpha=0.05 \quad \Sigma \mathrm{X}=461.59 \\
& N^{\prime}=\left(\frac{k}{S} \frac{\sqrt{N \Sigma x^{2}-(\Sigma x)^{2}}}{\Sigma x}\right)^{2} \\
& =\left(\frac{2}{0.05} \frac{\sqrt{(30 \times 7112.3-213067}}{445.652}\right)^{2} \\
& =2.364 \approx 30 \text { data }
\end{aligned}
$$

- $\quad$ ADBK rata-rata $=\frac{461.59}{30}=15.386$ 
$-\quad \sigma=\sqrt{\frac{10.5}{29}}=0.6017$

- $\quad \mathrm{UCL}=15.386+(3 \mathrm{X} 0.6017)=17.191467771$

- $\quad L C L=15.386-(3 X 0.6017)=13.581332229$

- $\quad \% \mathrm{RSD}=\frac{0.6017}{15.386} \times 100 \%=4 \%$

- $\quad \% 2 / 3 C V$ Horwitz $=2^{1-0.5 x \log ^{0.15386}}$

$$
=1,7667 \% \mathrm{~b} / \mathrm{b}
$$

- Sgabungan $_{\text {gab }}$

Diketahui: $\mathrm{N}_{1}=30 \quad \sigma_{1}{ }^{2}=0.452$

$$
\begin{aligned}
\mathrm{N}_{2} & =30 \quad \sigma_{2^{2}=0.6017} \\
S_{\text {gabungan }} & =\sqrt{\frac{\left(N_{1}-1\right) \sigma_{1}^{2}+\left(N_{2}-1\right) \sigma_{2}^{2}}{N_{1}+N_{2}-2}} \\
& =\sqrt{\frac{(30-1)(0.452)+(30-1)(0.6017)}{30+30-2}} \\
& =0.726
\end{aligned}
$$

- Uji T

$$
\begin{aligned}
& \text { Diketahui: } \mathrm{N}_{1}=30 \quad \overline{\mathrm{X}}_{1}=14.8551 \\
& \mathrm{~N}_{2}=30 \quad \overline{\mathrm{X}}_{2}=15.386
\end{aligned}
$$

$\mathrm{S}_{\text {gabungan }}=0.726$

$$
\begin{aligned}
T_{\text {hitung }} & =\frac{\overline{\mathrm{X}}_{1}-\overline{\mathrm{X}}_{2}}{S_{\text {gabungan }}\left(\sqrt{\frac{1}{N_{1}}}+\sqrt{\frac{1}{N_{2}}}\right)} \\
& =\frac{14.8551-15.386}{0.726\left(\sqrt{\frac{1}{30}}+\sqrt{\frac{1}{30}}\right)} \\
& =-2.004166631
\end{aligned}
$$

